\title{
A palaeoenvironmental investigation of two prehistoric burnt mound sites in
}

\section{Northern Ireland}

\author{
J. Wheeler ${ }^{1}$, S. Timpany ${ }^{2}$, T.M. Mighall ${ }^{1, *}$, L. Scott ${ }^{3}$ \\ ${ }^{1}$ Department of Geography \& Environment, School of Geosciences, University of \\ Aberdeen, Aberdeen, UK. \\ ${ }^{2}$ Department of Archaeology, Orkney College, Kirkwall, UK.
}

${ }^{3}$ Headland Archaeology (UK) Ltd, Edinburgh, UK.

*corresponding author:

E-mail address: t.mighall@abdn.ac.uk

\section{ABSTRACT}

This paper provides a summary of the palaeoenvironmental evidence from a spread of Late Mesolithic burnt material and two Late Neolithic to Early Bronze Age burnt mounds. The burnt mounds were up to $10 \mathrm{~m}$ diameter, had an amorphous shape and were consistently less than $0.8 \mathrm{~m}$ thick. Monoliths were collected from two sites, Ballygawley and Roughan, in Co. Tyrone, Northern Ireland. This provided an opportunity to use a detailed palaeoecological approach for the first time to investigate the use and function of burnt mounds. Pollen, non-pollen palynomorphs, micro- and macroscopic charcoal were used to place these features within their environmental context, and to establish if such an approach could provide further insights into their function. The palynological results shared similar characteristics: high microscopic charcoal values, repetitive fluctuations in tree and shrub taxa, increased Sphagnum and the presence of NPPs HdV-114 and HdV-146, all of which could be diagnostic indicators of burnt mound use in palynological records. While the data do not allow us to ascribe a specific function for the burnt mounds, their environmental setting is discussed. A 'seesaw' pattern of arboreal pollen, combined 
32 with the macroscopic charcoal data, indicate possible species selection and management of local woodland for fuelwood.

Keywords: Mesolithic, Late Neolithic, Early Bronze Age, burnt mounds, pollen, nonpollen palynomorphs, charcoal, Northern Ireland.

37

\section{INTRODUCTION}

Anthropogenically-constructed mounds commonly appear in the archaeological record and have various ages, shapes and sizes, as well as different types of construction material, including earth, stone and remnants of burnt fuel. These include presumed burial mounds, dating back 6000 years in Louisiana (Keenan \& Ellwood, 2014), earthen burial and platform mounds in southeast and southwest of North America (Lindauer \& Blitz, 1997; Pluckhahn et al., 2015) , the Stege Mounds (middens) of California (Eerkens et al., 2014), monumental building of flat-topped mounds in central Georgia, USA, (Bigman \& Lanzarone , 2014) and numerous PreColumbian earthworks to build dwellings in the Amazon (Lombardo \& Prümers, 2010). Outside the Americas, mounds are also widely distributed including the Anatolian mounds in the Near East (Steadman, 2000), the monumental mound of Silsbury Hill and burial mounds in southern Britain (Bayliss et al., 2007; Semple, 1998), and burnt mounds across the British Isles (Buckley, 1990).

Burnt mounds or 'fulacht fiadh' are a common feature in the Irish and British archaeological record (Brindley et al., 1989; Buckley, 1990; Feehan, 1991). They date from the Neolithic to the medieval period (Anthony et al, 2001; Ó Néill, 2009) and were widely used during the second millennium BC. They occur in various shapes and sizes. Crescent- or horseshoe- shaped burnt mounds are typical in Ireland but they can also be also circular, oval- and d-shaped. Their size ranges from over 1 
metre in height and range over 30 metres in diameter (O'Sullivan and Downey, 2004) whereas in north Wales burnt mounds have more amorphous shapes and sizes ranging from 3 metres in diameter to spreading over 15 metres (Fairburn, pers comm.) Despite being ubiquitous, we know little about their function. The most favoured hypothesis is cooking (O'Kelly, 1954; Hawkes, 2013) but this theory continues to be contested. Other alternative uses include brewing (Quinn \& Moore, 2007; Wilkins, 2011), butter-making (Sayce, 1945), bathing (O’Drisceòil, 1988), dying and textile processing (Jeffrey, 1991), butchery (Tourunen, 2008), leather working, saunas/sweat lodges and baths (Barfield and Hodder, 1987; O'Sullivan and Downey, 2004), the rendering of animal fats (Monk, 2007) and funerary and ritual practices (Bradley, 1978). However, cooking continues to be the most likely activity (Hawkes, 2013). There have been few attempts to progress these generalised interpretations. Whilst these functions are plausible, all are falsifiable and require convincing evidence. Consequently burnt mounds remain an archaeological enigma. Few palaeoenvironmental studies have focussed specifically on understanding the function and wider environmental context of burnt mounds (e.g. Innes, 1998; Gonzalez et al., 2000). Palaeoenvironmental analyses can provide useful insights into the history and function of an archaeological site and provide an environmental setting for past activities (Dimbleby, 1985; Whittington and Edwards, 1994; Tipping et al, 2009). The combination of palynological and anthracological studies is now well established to provide complementary data sets to investigate changes in woodland composition (Gowen et al., 2005; Newman et al., 2007; Nelle et al., 2010) and management (Ludemann et al., 2004; Mighall et al., 2010; Wheeler, 2011; Crew and Mighall, 2013). Such an approach is adopted in this study. The study 
82 aims to: (i) place these burnt mounds into their environmental context; (ii)

83 reconstruct any vegetational changes associated with the use of the burnt mounds

84 using pollen, NPPs, microscopic charcoal data and archaeo-anthracological data; and

85 (iii) determine if the palaeoenvironmental record can provide insights into the

86 function of burnt mounds.

89 This study centres around two Late Neolithic/Early Bronze Age burnt mounds from two sites, Ballygawley and Roughan. Palaeoenvironmental sampling was carried out as part of the archaeological evaluation and excavation strategy associated with the A4/5 road improvement scheme between Dungallen and Ballygawley, Co Tyrone, Northern Ireland, undertaken by Headland Archaeology Ltd. A total of 25 sites were evaluated, with 12 of these sites going on to excavation, between August 2006 and April 2007. Excavation across these sites revealed 29 burnt mounds and associated features (e.g. hearths and troughs), Bronze Age cremation burials and ring ditches, two Early Christian ringforts, and an Early Christian cemetery (Figure 1a, b).

\section{Ballygawley} The Ballygawley site is located in low lying pasture approximately $5 \mathrm{~km}$ east

101 of the Ballygawley Water, on the edge of the floodplain that lies at the foot of higher 102 ground formed by drumlins (Figure 1b, c). Palaeochannels and alluvial islands, 103 representing a system of lateral migration and anastomosing channels (Lewin et al., 104 2005), run across the site. These palaeochannels were infilled with intercalated 
deposits of peats and alluvial silts and clays (Figure 1c). Upon excavation 23 burnt mounds were discovered, including ten wooden and wicker-lined troughs (in eight different styles) dated from the Neolithic to the medieval period (e.g. Supplementary Figure 1a,b), some being Sphagnum lined and with associated pits and hearths (Bailey, 2010a; Bamforth et al., 2010). The analysis of planks and wattle sails, which were made of mainly hazel, used in the construction of troughs associated with the burnt mounds suggest that some form of woodland management was practiced, possibly coppicing or new growth cut within an interval of less than 10 years (Bamforth et al., 2010). One burnt mound deposit (9031) was sampled at this location, measuring $3.7 \mathrm{~m} \times 3.2 \mathrm{~m}$. The deposit was up to $0.14 \mathrm{~m}$ thick (Bailey, 2010a).

A monolith was collected from the northern limit of excavation and truncated a single-phase section of burnt mound [context no 9031] (Figure 1c). Charcoal from the base of the feature was radiocarbon-dated to $3865 \pm 35$ (2465-2210 cal yr BC, $2 \sigma ; \mathrm{GU}-17350)$. A section of the stratigraphy of the sediments is shown the figure $2 \mathrm{a}$. A radiocarbon chronology of these features indicates that activity took place at Ballygawley from c. 3350 cal yr BC to cal yr AD 1270 (Supplementary Figure 2); with six burnt mounds dated to the Late Neolithic to Early Bronze Age. The earliest

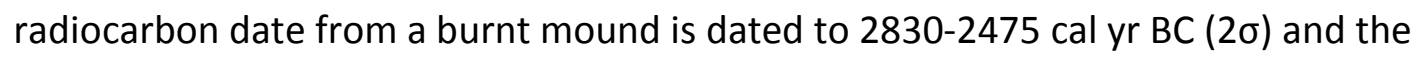
youngest has been dated to cal yr AD 1040-1220 (2б). A hiatus of activity of approximately 900 years occurred between the Late Iron Age and early medieval period at the site, yet the overall longevity of activity indicates Ballygawley was a place that people returned to in order to use hot stone technology. The construction 
128 of new burnt mounds followed the migration of the palaeochannels and their

129 changing course to maintain access and proximity to a water supply (Figure 1c).

130 The finds assemblage recovered from Ballygawley is amongst the largest

131 from any Irish burnt mound complex, with a considerable quantity of material

132 coming from the palaeochannel deposits. The majority of finds were of prehistoric

133 age including pottery fragments relating to five different vessels from the Late

134 Neolithic/Early Bronze Age, together with 16 flint scrapers and two bone points

135 indicative of butchery practices and hide preparation. Butchery is also indicated by

136 the faunal bone assemblage, which consists of cattle, pig and sheep/goat, largely

137 contains parts associated with slaughter (skull, mandible, lower leg bones) and

138 primary butchery (upper leg bones) (Tourunen, 2009). However, the lack of blades

139 recovered suggests meat preparation was not taking place (Lochrie, 2010a, 2010b,

140 2010c).

141

142 Roughan

143 Roughan is located on an area of low-lying pasture approximately $9 \mathrm{~km}$ to the south

144 west of Ballygawley (Figure 1d), fringing an area of reclaimed peatland. The site lies

145 within a small valley running from east to west with ground rising to the north and

146 further low-lying land to the south. Excavations at Roughan revealed a group of six

147 burnt mounds, which are amorphous in shape ranging from $1 \mathrm{~m}$ to $10 \mathrm{~m}$ diameter

148 and less than $1 \mathrm{~m}$ thick (Figure $1 \mathrm{e}$ ). Burnt mound ( 8413 ) measured $8.80 \mathrm{~m}$ by $4.90 \mathrm{~m}$

149 and up to $0.25 \mathrm{~m}$ thick. Associated features included troughs and pits. Troughs were

150 found to be mainly unlined, although one trough did contain a layer of organic

151 material which may have been the remains of a lining (Bailey, 2010b). 
153 had been two possible attempts to stabilize the surface of the peat around the burnt

154 mounds during prehistory. The first used collected brushwood (no evidence of tool

155 marks were found (Bamforth et al., 2010)) and the second utilized actual burnt

156 mound material in a linear spread leading from one of the mounds (Bailey, 2010b).

157 There was a dearth of finds at Roughan.

158 A monolith was taken through the base of one of the burnt mounds [context 159 no 8413] (Figure 1e; Figure 2b, c). A radiocarbon date (3885 $\pm 35 ; 2466-2208$ cal yr BC; 160 GU-15850) places this feature into the Bronze Age, and is comparable with a series 161 of radiocarbon dates from other features which suggest that burnt mound use took 162 place during the third millennium BC between c. 2900 to $2100 \mathrm{cal}$ yr BC

163 (Supplementary Figure 3). An earlier spread of burnt material was discovered at the 164 base of the monolith, confirmed by radiocarbon dating to be of Late Mesolithic age 165 c. $6400-5900$ cal yr BC (Supplementary Figure 3).

\section{METHODS AND MATERIALS}

168 In order to obtain pollen sequences that could be linked directly to periods of burnt 169 mound use, it was decided to take samples directly through the mounds. Monoliths 170 were analysed which encompassed the burnt mound layers (charcoal and heat-

171 fractured stone), together with intercalated peat and/or alluvial deposits. This 172 allowed for the close-interval sampling for periods of activity immediately preceding, 173 during and after burnt mound use. 
Sub-samples from both monoliths were taken over selected intervals $(112-66 \mathrm{~cm}$ at

177

178

180

Ballygawley and from 58 to $18 \mathrm{~cm}$ at Roughan). Each $1 \mathrm{~cm}^{3}$ sub-sample was prepared for pollen and NPPs analyses following Barber (1976). The organic component of each sub-sample was separated from the mineral component using density flotation (Nakagawa et al., 1998). A sum of 500 total land pollen (TLP) was achieved for all sub-samples except for the burnt mound material at Ballygawley. Data are expressed as a percentage of the TLP, with spores and aquatic taxa excluded from the TLP sum. NPPs were also counted during routine pollen analysis (cf. van Geel et al. 1982/1983, 2003) and they are expressed as a percentage of TLP plus total NPPs. Rare types are indicated by a cross $(+)$, where one cross is equal to one pollen grain or NPP. Pollen samples were spiked with Lycopodium clavatum tablets (Stockmarr, 1971) in order to calculate pollen concentrations using the method described by Benninghoff (1962). Identification, including cereal-type pollen, was aided by reference keys in Fægri et al. (1989), Moore et al. (1991), Beug (2004) and Reille (1999), and supported by a modern type-slide reference collection housed at the University of Aberdeen. As the separation of Myrica gale from Corylus avellana-type can be difficult these pollen grain types are classified as Corylus avellana-type (Edwards 1981). Plant nomenclature follows Stace (2001). Basic land use designations interpreted from the pollen records follow Brown et al.(2007). Microscopic charcoal was counted in three fractions $(<21 \mu \mathrm{m}, 21-50 \mu \mathrm{m}$, and $>50 \mu \mathrm{m})$. Loss on Ignition percentages (LOI) were also determined (Schulte and Hopkins, 1996).

\section{Radiocarbon dating}


199 Selected bulk sediment, humic acid fraction or charcoal samples were carefully

200 extracted from the monoliths and submitted to the NERC Radiocarbon Laboratory

201 and Poznań Radiocarbon Laboratory for AMS radiocarbon dating.

\section{Macroscopic charcoal}

204 A maximum of fifty charcoal fragments were selected from each sub-sample based

205 on size to allow for positive species identification and also to maximise ring

206 curvature data. The standardised quantitative sampling strategy (Asouti, 2001;

207 Wheeler, 2007) was deemed appropriate to provide adequate material for inter-

208 feature/inter-site assessments. Standard methods of identification followed Leney \&

209 Casteel (1975) with charcoal samples being fractured to reveal the three sectional

210 surfaces (transverse section (TS), tangential longitudinal section (TLS), and radial

211 longitudinal section (RLS) necessary for microscopic wood-type identification to

212 genus. Charcoal fragments were securely positioned onto slides for examination

213 under an incident light microscope at magnification 100x, 200x and 400x.

214 Identifications were assisted by using wood keys by Schweingruber (1990) and a

215 modern reference collection. Nomenclature follows Schweingruber (1990). Ring

216 curvature was measured using the key in Marguerie and Hunot (2007): where weak

217 curvature is thought to denote large-sized timbers; medium curvature, medium-

218 sized timbers; and strong curvature representative of small-sized timbers or

219 branchwood. When ring curvature could not be observed or genus not identified, an

220 indeterminate result was recorded. 
224 The monoliths were described using the Troels Smith (1955) classification and they 225 are provided in Table SI1.

226

227

228

229

230

231

232

233

234

235

236

237

238

239

240

\section{Stratigraphy}

\section{Radiocarbon Dating}

All radiocarbon dates quoted in this paper are listed in Table 1 and Supplementary Figures 1 and 2. The radiocarbon dates are given to $+1 \sigma$ and calibrated ages to a two $\sigma$ age range, using Calib 7.0 software (Reimer et al., 2009) in conjunction with Stuiver and Reimer (1993). An age-depth model for Roughan was constructed using CLAM (Blaauw, 2010) and shown in Figure 3. As clay dominated the stratigraphy at Ballygawley prevented reliable dates from being obtained on sediment above the burnt mound material. Only two radiocarbon dates were determined at the top and bottom of the burnt mound and this is considered an insufficient number to model.

There are some uncertainties with all radiocarbon dates and some of these might apply to this study. There has been some discussion over which fraction of the peat to date (Shore et al., 1995; Brock et al., 2011). Dating the humic acid fraction of a sample can be problematic as humic acids are mobile and generally yield dates which are younger than the humin fraction of the same sample (Shore et al., 1995;

Brock et al., 2011). For example, Bartley and Chambers (1992) suggest that the humin fraction is preferable for dating purposes although Johnson et al. (1990) recommend using the humic acid fraction in certain contexts. AMS dates from bulk sediment can also be badly skewed by small amounts of intrusive material (e.g. Chapman and Gearey, 2013). There could be a significant old wood offset with 
radiocarbon dates obtained from charcoal and charcoal of different ages could have

248 been included in the same deposit (Pilcher, 1991). Moreover, the differences in ages

249 between GU-15850 and GU-15852 indicate a possible hiatus or very slow rates of

250 accumulation. There is significant potential for disturbance to the on-site deposits

251 given the evidence for repeated human activity.

252 While recognising the limitations described above, radiocarbon dates from

253 the humic acid fraction and charcoal at Ballygawley (GU-15849 \& GU-17350) do not

254 have any great offset compared to one another, and dates from bulk sediment and

255 the humic acid fraction at Roughan produce similar ages (GU-15852 \& Poz-46459).

256 Furthermore, the radiocarbon dates from Ballygawley and one from Roughan (GU-

257 15850) fit the chronological framework provided by the radiocarbon dates from

258 other archaeological structures at these sites (Figure SI2 \& 3). Any age-offset is

259 therefore not considered to adversely affect comparisons with the

260 palaeoenvironmental records and the archaeological features.

261 When interpreting fossil peat archives, Telford et al. (2004) and Piotrowska et

262 al. (2010/2011) consider that all radiocarbon dates and all age-depth models are

263 uncertain. The limited number of radiocarbon dates (3 for Roughan and 2 for

264 Ballgawley) associated with the monolith sequences compromise the robustness of

265 the CLAM age-depth models (Figure 3). Therefore the models should be treated with

266 caution. Unless stated otherwise all cited ages are derived as best estimates from

267 the CLAM models.

268

269 Microfossils 
The pollen and non-pollen palynomorphs (NPPs) diagrams for both monoliths were

271 constructed using Tilia.graph (Grimm, 2004) and are presented in Figures 4, 5, 6 and

272 7. The diagrams have been divided into local pollen assemblage zones (LPAZs) using

273 CONISS (Grimm 1987). Preservation is variable across all zones in both diagrams.

274 Poor pollen preservation ranges between 20 and $40 \%$ across all damaged categories

275 of indeterminate pollen; with the exception of two sequences of raised

276 indeterminate peaks in Ballygawley LPAZ BG1.

277

278 INTERPRETATION

279 Ballygawley

$B G 1(113-102 \mathrm{~cm})$ (Figures 4 and 5)

281 A Late Neolithic date (c. 2470-2270 cal yr BC) was determined for the top of this zone. Tree and shrub percentages exceed $60 \%$ TLP and indicate local woodland. As

283 Martin and Mehringer (1965) have shown, most pollen found in alluvial sediments is

284 derived from a local source. Therefore, the high values of Alnus, Salix and possibly

285 Corylus avellana-type are indicative of a local carr (Waller et al. 2005). Deciduous

286 woodland, whilst local, was probably situated on higher ground, and is characterised

287 by Quercus, Corylus avellana-type, Betula and Ulmus with Polypodium occupying

288 shaded areas beneath the woodland canopy. Repetitive peaks and troughs create a

289 'see-saw' pattern in the pollen curves for Corylus avellana-type and also for Quercus,

290 Alnus and Poaceae at the base of the burnt mound material (from $107 \mathrm{~cm}$ up core).

291 Rough, wet pasture is inferred by the representation of Plantago lanceolata,

292 Ranunculaceae, Rumex acetosa, Aster-type and Caryophyllaceae (Brown et al., 
294 Filipendula are all commonly found on fens. Indicators of disturbance include

295 Chenopodiaceae and Urtica.

The pollen record in the basal zone, immediately before the deposition of the

297 burnt mound deposits, is characterised by a number of noteworthy observations. As

298 expected, microscopic charcoal counts, indicative of burning, increased from $105 \mathrm{~cm}$

299 with this rise sustained until $94 \mathrm{~cm}$. Wood detritus can be inferred from the

300 occurrence of scalariform perforation plates (SPPs) (HdV-114), which peaked at

$301106.5 \mathrm{~cm}$, and grazing and/or the presence of decayed wood from Sordaria-type

302 (HdV-55A). Small peaks in Glomus cf. fasciculatum chlamydospores (HdV-207)

303 between $107 \mathrm{~cm}$ and $105 \mathrm{~cm}$ may also represent an inwash of debris as this

304 particular NPP is considered to be a marker for erosion in fluvial/lacustrine contexts

305 (van Geel et al., 1983, 2003) but not for peat (Kołaczek et al., 2013). HdV-184 is

306 associated with the deposition of sandy clay (van Geel, 1983).

307 Relatively high amounts of indeterminate, degraded, folded/crumpled and

308 corroded pollen grains occurred throughout the zone, which most likely represents

309 inwash from the palaeochannels (Delcourt and Delcourt, 1980; Moore et al., 1991).

310 Pollen corrosion and degradation can also be caused by chemical and biochemical

311 oxidation, raised $\mathrm{pH}$ (Moore et al., 1991) and/or the result of increased

312 eutrophication. Eutrophication is suggested by the presence of HdV-150 and HdV-

313 167. Gloeotrichia (HdV-146), an aquatic pioneer, is indicative of nutrient poor

314 conditions and has the ability to fix nitrogen (van Geel, 2005). Consistently higher

315 numbers of Sphagnum spores and the occurrence of Tilletia sphagni (HdV-27) at 106

$316 \mathrm{~cm}$ were recorded. These features all occurred from $107 \mathrm{~cm}$ depth, which is 
tentatively dated using a polynominal regression age-depth model (using Clam;

Blaauw, 2010) to a best estimate of c. 2760 cal yr BC. The earliest burnt mound use

319 (BM 9003, see Figure 1c) at the site is dated to 2833 to 2475 cal yr BC and therefore

320 the changes described above could be associated with contemporary burnt mound

321 use.

LPAZ BG2 (102-94.5cm)

324 The age-model model tentatively places this zone between c. 2470 and $2200 \mathrm{cal}$ yr

325 BC. At $103 \mathrm{~cm}$ the stratigraphy changed from clay to burnt mound material. The

326 burnt mound material appears to have been deposited over a short period of time as

327 indicated by the radiocarbon dates. High microscopic charcoal values characterise

328 this zone, indicative of intense burning. This has adversely affected the preservation

329 of pollen, probably as a result of exposure to high temperatures (Delcourt and

330 Delcourt, 1980; Havinga, 1967). This possibly explains the loss of the repetitive

331 fluctuations of tree taxa and the decline in total tree pollen percentages. Although

332 the latter might also be the result of a loss of woodland cover as a result of sustained

333 burnt mound use from c. 2800 cal yr BC to $1420 \mathrm{cal} \mathrm{yr} \mathrm{BC.} \mathrm{Sphagnum} \mathrm{(used} \mathrm{as} \mathrm{a}$

334 lining in the burnt mound troughs) peaked but SPPs (HdV-114) and Gloeotrichia

335 (HdV-146) were only recorded in trace amounts until $96 \mathrm{~cm}$ when both increased in

336 percentage. HdV-184 was regularly recorded in trace amounts, being associated with

337 the deposition of sandy clay.

The occasional trace of Poaceae $>35 \mu \mathrm{m}$ may be representative of cereal-

339 types and/or wild grasses (Dickson, 1988; Edwards and Borthwick, 2010), possibly in 340 wet meadow/fen or within the floodplain system along with Cyperaceae and 
Peucedanum palustre-type. The lack of cultural, herbaceous pollen taxa is probably

342 the result of poor pollen preservation rather than a lack of human activity or grazing.

343 Cercophora-type (HdV-112) and Sordaria-type (HdV-55A) were recorded at the end

344 of the LPAZ suggesting low intensity grazing and/or the presence of decayed wood.

345 Whereas the re-occurrence of Glomus cf. fasciculatum chlamydospores (HdV-207)

346 can be associated with the inwash of eroded material.

LPAZ BG3 $(94.5-75 \mathrm{~cm})$

349 The age range of this zone is uncertain given the lack of radiocarbon dates for the top $90 \mathrm{~cm}$. An immediate decline in microscopic charcoal in this zone suggests the use of the burnt mound [context no 9031; Figure 1c] subsided. The continual

352 presence of microscopic charcoal implies less intense burning in the immediate 353 vicinity (>50 $\mu \mathrm{m}$ fraction), and/or more distant burning, most probably within the 354 wider burnt mound complex ( $<21 \mu \mathrm{m}$ and $21-50 \mu \mathrm{m}$ fractions). However, the 355 radiocarbon chronology across the site suggests a pause in burnt mound use 356 between c. 2100 and 1900 cal yr BC. The pollen and NPP records replicate those observed in the end of LPAZ BG1.

358 Relatively stable total arboreal pollen (AP) percentages, similar to those noted just 359 before the deposition of the burnt mound material, were recorded. Repetitive 360 changes in Corylus avellana-type and possibly Quercus continued until $89 \mathrm{~cm}$ but the 361 pattern is less evident for Alnus, Ulmus and Betula. Wet pasture/marsh indicators 362 were present including Poaceae $>35 \mu \mathrm{m}$, Rumex acetosa and Plantago lanceolata, 363 Cyperaceae, Galium-type and Peucedanum palustre-type, together with indicators 364 of disturbed ground, such as Chenopodiaceae and Apiaceae (Brown et al., 2007). 
Coprophilous fungi Cercophora-type (HdV-112) and Sordaria-type (HdV-55A) were also recorded suggesting that herbivores grazed nearby (Mighall et al., 2008). Sphagnum, SPPs (HdV-114) and Gloeotrichia (HdV-146) all reappeared and may relate to continued burnt mound use, which could have continued for approximately another 100 years in proximity of the sampling site. These patterns continued until approximately $87 \mathrm{~cm}$ when the sampling resolution becomes coarser and/or activities on the site either changed or ceased.

Microscopic charcoal values increased slightly at $85 \mathrm{~cm}$ and may reflect a resumption of burnt mound use at the site (for e.g.) BM9011 at location 9009; Figure 4). This activity did not have a major impact on woodland cover. Total tree and shrub percentages did not diminish but show a pattern of occasional decline and recovery. Grazing indicators Cercophora-type (HdV-112) and Sordaria-type (HdV-55A) occurred in trace amounts. A suite of herbaceous taxa normally associated with pasture (Brown et al., 2007) were recorded in trace amounts, including Ranunculaceae, Rumex acetosella, Plantago lanceolata, Plantago media/major and Caryophyllaceae. Urtica, Sphagnum, SPPs (HdV-114) and Gloeotrichia-type (HdV-146) were also regularly recorded but at much lower values. Tilletia sphagni (HdV-27) occurred sporadically.

\section{LPAZ BG4 (75-66 cm)}

Mixed carr and deciduous woodland, comprising Alnus, Salix, Corylus avellana-type, Quercus and UImus, were still present locally. Corylus avellana-type pollen values see-sawed again. Poaceae has an inverse pattern with Corylus avellana-type. The appearance of cereal-type pollen at $72 \mathrm{~cm}$ and Triticum-type (wheat) pollen at $70 \mathrm{~cm}$ 
implies the onset of small-scale cereal cultivation. Their occurrence corresponds with a continual presence of Plantago lanceolata and Plantago media/major. Aster-type

391 and other indicators of disturbed ground and pasture remained present from the preceding zone but only in trace amounts. Any grazing, as suggested by the presence of Sordaria-type (HdV-55A), appears to have been at a lower intensity at this time. LOI peaked at $72 \mathrm{~cm}$ suggesting that inwash from the palaeochannel has subsided.

Microscopic charcoal values remained fairly stable and might be related to another phase of burnt mound activity. Gloeotrichia-type, SPPs (HdV-114) and Sphagnum were all recorded but sporadically and in low values. If changes in these taxa were related to burnt mound use, they were minor, despite the sampling site being within 100-150 metres.

400

\section{Roughan}

402

\section{LPAZ Rou1 (Figures 6 \& 7)}

The radiocarbon date of 6385-6100 cal yr BC at 51-52 cm (Poz-46459) confirms a

404 Late Mesolithic date for this LPAZ. Corylus avellana-type pollen was abundant, peaking at $51-50 \mathrm{~cm}$, indicating a strong local presence of hazel and typical of early

406 Holocene woodlands across the British Isles (Huntley, 1993). Its abundance might 407 relate to quantitative over-representation (Binney et al., 2005). Pinus, Betula, 408 Quercus and Ulmus formed mixed woodland with Corylus. Fluctuations in the pollen 409 of Corylus avellana-type, and to a lesser extent, Quercus, Ulmus, Alnus, Betula and 410 Salix created a 'see-saw' pattern in the total tree and shrub pollen sum leading up to 411 the deposition of burnt material. The presence of Viburnum in association with 412 Prunus-type (P. avium and P. spinosa were both present in the charcoal record) 
413

suggests open woodland, possibly comprising fringe vegetation with enough shade to support pteridophytes. Carr woodland, comprising Alnus and Salix, was also present. Rough wet grassland and/or damp woodland floor indicators were present, including Poaceae, Cyperaceae, Aster-type, Narthecium ossifragum, Filipendula and Galium-type. Disturbed ground taxa (e.g. Urtica and Apiaceae) also occurred (Brown et al., 2007). The presence of Urtica suggests that local soils had relatively high nutrient levels (Yeloff et al., 2007). SPPs (HdV-114), indicative of woody debris, and Glomus cf. fasciculatum chlamydospores (HdV-207) appear to be associated with the inwash of eroded material. HdV-150 and 167 indicate shallow eutrophic water. In contrast, Gloeotrichia-type (HdV-146) indicates the presence of nitrogen poor conditions (van Geel, 2005). Sphagnum was also consistently recorded.

\section{LPAZ Rou2}

This LPAZ represents the burnt material. Two radiocarbon dates either side of this deposit confirm the burning took place during the Mesolithic (Table 1). There is a cross-fraction increase of microscopic charcoal across the LPAZ boundary and values remain much higher throughout the burnt material. It is not clear whether this represented a fire deliberately set by humans or a natural occurrence (cf. Chambers, 1993). An increase in the total amount of tree pollen was characterised by Alnus and Quercus, whereas Corylus avellana-type declined from $72 \%$ to $56 \%$ TLP, allowing for the greater representation of other trees and shrubs (Waller et al., 2005). This fluctuation could represent an actual change in woodland structure, or alternatively be a taphonomic variable. Ilex and Prunus-type suggest that woodland was open. 
woodland or at the woodland edge. Some taxa, considered to be disturbance

439 indicators (e.g. Apiaceae and Urtica; Brown et al., 2007), recorded in the microfossil

440 diagrams may reflect natural perturbations operating in a floodplain environment

441 (e.g. Anderson et al., 2000). Herbivores may have grazed pasture and/or wet

442 meadow close by as Sordaria-type (HdV-55A) also occurred. Sordaria-types HdV-

$44355 \mathrm{~A} / \mathrm{B}$ are commonly recorded during Mesolithic disturbance phases suggesting the

444 presence of dead wood and/or that animals were making use of openings in

445 woodland (Mighall et al., 2008). Obligate coprophilous fungi, however, have not

446 been recorded. The lack of these fungi supports the idea that these disturbances are

447 natural as is it possible that the fungi occurred on dead wood. Woody debris is also

448 indicated by the presence of SPPs (HdV-114) throughout the burnt material. Glomus

449 cf. fasciculatum (HdV-207) and Eurycerus cf. lamellatus (HdV-72D) may also

450 represent an inwash of debris (van Geel et al., 1982/83, 2003).

451 Wet meadow/fen vegetation is inferred locally by the presence of Poaceae

452 (including those $>35 \mu \mathrm{m}$ ), Cyperaceae, Filipendula and Peucedanum palustre-type.

453 Taxa often associated with pasture and disturbance were also recorded in trace

454 amounts, including Apiaceae, Ranunculaceae, Plantago lanceolata, Rumex acetosa,

455 Aster-type and Caryophyllaceae (Brown et al., 2007). Indicators of nutrient poor

456 conditions included Sphagnum and Gloeotrichia-type (HdV-146).

LPAZ Rou3

459 The radiocarbon date of 6070-5910 cal yr BC (GU-15852) at 43-42 cm provides a Late

460 Mesolithic date for the beginning of this LPAZ which culminates in the Late Neolithic, 

by the steady, gradual rise of total tree pollen. Immediately after the deposition of burnt material ends a see-saw pattern was observed in many of the tree and shrub taxa and Poaceae percentages. Percentages of Salix and, to a lesser extent, Pinus, Betula, Quercus, Corylus avellana-type and Cyperaceae have an inverse relationship to Alnus and Poaceae. A strong signal of Salix pollen suggests local on-site growth (Waller et al., 2005) which may have replaced Corylus on the floodplain as its percentages decrease from the start of the zone to $38 \mathrm{~cm}$. A constant background signal for burning is inferred from the microscopic charcoal, which is dominated by the $<21 \mu \mathrm{m}$ fraction, until the upper part of the LPAZ. These patterns continued until approximately $38 \mathrm{~cm}$ (c. $5520 \mathrm{cal}$ yr BC) when the sampling resolution becomes coarser. expansion of wet grassland/fen. Taxa often associated with pasture and disturbance were also recorded in trace amounts, and albeit more sporadically than compared to the previous zone. Such taxa include Apiaceae, Ranunculaceae, Plantago lanceolata, Rumex acetosa, Aster-type, Artemisia-type, Caryophyllaceae and Urtica. Isolated traces of Sordaria-type (HdV-55A) and Cercophora-type (HdV-112) indicate that grazing may have occurred locally. Agropyron-type (wheat-grass) is recorded as a

480 rare-type mid-LPAZ; it is possible that it was used by humans as the leaves, tuber and 481 seeds are edible, and the roots also produce a grey dye (Coon, 1978). The total percentage of trees and shrubs peaked at $23 \mathrm{~cm}$. The finer

483 resolution of the pollen data reveals a see-saw pattern particularly for Salix and 484 Poaceae. The major tree taxa also fluctuate: Pinus, Quercus, Ulmus and Corylus 
generally have an inverse relationship with Alnus. These changes may be a response to the decline of relatively high pollen producers such as Alnus and Poaceae. Once Alnus and Poaceae recover and started to produce large quantities of local pollen, the dispersal of pollen particularly from the trunk space and canopy signal from the trees on higher, drier ground became spatially restricted.

Grazing intensity appeared to increase from $22 \mathrm{~cm}$ as the amount of Sordaria-type (HdV-55A) rose. This observation is supported by the increased occurrence of pasture and disturbance indicators, including Poaceae and Chenopodiaceae from $24 \mathrm{~cm}$ to the top of the LPAZ. Microscopic charcoal values peaked at $22 \mathrm{~cm}$ and remained slightly higher, especially the $<21$ and $21-50 \mu \mathrm{m}$ fractions. This suggests increased burning, and may represent a major phase of burnt mound use at the site. A burnt spread (context 8467) and mound (context 8422) have been radiocarbon dated to the Neolithic period c. 2850 cal yr BC (Supplementary Figure 3), which equates to $22 \mathrm{~cm}$ in the pollen diagram. This represents a new phase of activity at the site with activity lasting until c. 2040 cal yr BC. Local soils appear to become less eutrophic at this time as Urtica percentages fall in value throughout the LPAZ.

Sphagnum was recorded at consistently higher levels from $34 \mathrm{~cm}$ onwards, together with HdV-146 (Gloeotrichia-type). The occurrence of HdV-62, HdV-128 and HdV-143 on the upper LPAZ zone boundary indicates that the water was meso- to eutrophic (van Geel, 1978; van Geel et al., 2003). Woody debris and decomposed wood is indicated by HdV-114 and an isolated occurrence of Kretzschmaria deusta (HdV-44). This may indicate the presence of local trees as the ascospores are 
generally dispersed only several metres from their source (van Geel, 2005), but they may have travelled further within the palaeochannel network.

\section{LPAZ Rou4}

The radiocarbon date at 19-18 cm provides a Late Neolithic/Early Bronze Age date of 2466-2208 cal yr BC (GU-15850; Table 1) for the charcoal (considered part of the burnt mound material) at the top of the sequence. Repetitive fluctuations in Corylus avellana-type, Alnus, Quercus, Pinus and Ulmus were apparent in the arboreal and shrub pollen sums. The synchronicity between Alnus and Poaceae weakened. Alnus and Quercus had an inverse relationship with Corylus avellana-type. Fluctuations were also witnessed in the Poaceae and Cyperaceae pollen curves. Rises in microcharcoal counts across all fractions also began at this point, being most evident in the lowermost sample of the burnt material.

Other changes observed in association with burnt material were also recorded. Sphagnum increased slightly, together with possible woody debris indicators Sordaria-type (HdV-55A) and SPPs (HdV-114); the latter being representative of Betula, Alnus or Corylus (van Geel, 1978; Hather, 2000). Increases in eutrophy are suggested by the presence of Zygnemataceae (HdV-62), Diporotheca rhizophila (HdV-143) and HdV-128 (van Geel et al., 1983; Kuhry, 1985).

Fen/wet meadow vegetation remained present, which may have been used for grazing animals due to the presence of possible disturbance indicators Cicuta virosa, Plantago media/major pollen and the reappearance of coprophilous fungal spores: Sporormiella-type (HdV-113) and Cercophora-type (HdV-112) (van Geel et al., 2003). Their presence coincided with a large increase of microscopic charcoal at 
551 fruitwoods and Sorbus sp. Trace amounts of Prunus-type are regularly recorded at

$18.5 \mathrm{~cm}$ and, assuming the monolith chronology is sufficiently robust, the probable resumption of burnt mound use across the site (Figures 5, 6).

\section{Macroscopic charcoal}

The charcoal results presented are collated from those burnt mounds and associated features (e.g. troughs and pits) that have been dated to the Late Neolithic to Early Bronze Age period are shown in Figures 8 and 9. Notwithstanding the limitations of the age-depth models, they are of broadly comparable age to the pollen sequences taken at Ballygawley through burnt mound [9031], and at Roughan through burnt mound [8413].

The charcoal condition varied from firm and well preserved to poor and friable. In some cases charcoal fragments were partially vitrified, caused by exposure to temperatures in excess of $800^{\circ} \mathrm{C}$ (Prior and Alvin, 1983). A fraction of the charcoal assemblage was in a poor condition due to orange mineral discolouration, a common feature associated with material from burnt mounds, as waterlogged conditions can result in the charcoal incorporating minerals such as calcium and iron, which hinders identification (Stuijts, 2007). The anthracological information gained from the charcoal analysis provides a complementary data set to the pollen analysis and reveals the presence of insect pollinated arboreal taxa such as Maloideae sp. both sites. However, these taxa are low pollen producers, with their pollen being difficult to detect, unless they grow close to the sampling site (Stuijts 2005).

\section{Ballygawley}


556 A total of 1109 charcoal fragments were analysed from six burnt mound groups of

557 Late Neolithic to Early Bronze Age date (Figure 8). Eleven different taxa were

558 identified as fuelwood from the burnt mound deposits. Individual mounds have

559 fuelwood assemblages of between 1 and 10 taxa. However, a potential skewing of

560 results is acknowledged as some burnt mound features have more samples analysed

561 than others (e.g. burnt mound [9782] compared with burnt mound [9031]). The

562 most dominant taxa within the assemblage are Alnus glutinosa and Corylus avellana,

563 with Alnus glutinosa in particular being prominent in all six burnt mound deposits,

564 and especially from burnt mounds 9782, 9034 and 9986. Other taxa present include

565 Salix sp., Quercus sp., Maloideae sp. (a group including Pyrus communis, Malus

566 sylvestris and Crataegus sp., which cannot be differentiated based on their

567 anatomical composition), Ulmus sp. and Prunus avium, together with Prunus spinosa.

568 The growth ring curvature of the charcoal fragments indicates that all taxa

569 were representative of small- to medium-sized wood, with strongly to moderately

570 curved growth rings, suggesting the bulk of the fuel wood assemblage consisted of

571 branch wood. Large-sized timbers, such as trunk wood indicated by weakly curved

572 growth rings were also present in the assemblage, and were limited to three taxa:

573 Quercus sp., Corylus avellana and Alnus glutinosa.

574

575 Roughan

576 A total of 601 charcoal fragments were analysed from five burnt mound (or spread)

577 groups of Late Neolithic to Early Bronze Age date (Figure 9). Eight taxa were

578 identified at Roughan. Alnus glutinosa is the dominant fuel wood but it is not most

579 prevalent in all burnt mound fuel wood deposits. Corylus avellana and Quercus sp. 

are the most abundant species within the assemblage. Other taxa identified include Betula sp., Salix sp., Ulmus sp., Prunus avium and Prunus spinosa. The growth ring curvature of the charcoal fragments from Roughan is similar to that at Ballygawley with all taxa present being represented by strongly to moderately curved growth rings. This indicates the use of small- to medium-sized timbers suggestive of branch wood. However, there is more variety of taxa with weakly-curved growth rings suggesting the utilisation of large-sized timbers with six taxa represented: Quercus sp., Corylus avellana, Betula sp., Alnus glutinosa, Salix sp. and Prunus avium.

\section{DISCUSSION}

\section{Mesolithic burning}

592 The earliest evidence of burning has been dated to the Late Mesolithic period at

593 Roughan. This episode of burning has been labelled a "burnt spread" as no related

594 features or finds were discovered. Only a single fragment of Corylus avellana

595 charcoal was found in the spread. The pollen data indicate that burning of Corylus-

596 scrub woodland took place (Figure 6a). Burning appears to have been spatially

597 constrained as other tree and shrub taxa do not appear to have been adversely

598 affected except Salix which was possibly used for fuel but without charcoal data it is 599 difficult to establish. Simmons and Innes (1996) suggested that Mesolithic peoples deliberately

601 burnt the ground layer of woodlands or exploited naturally created openings to 602 encourage browsing of animals. In the absence of any archaeological evidence for 603 Mesolithic activity in this study, it is not possible to firmly ascribe this burning 
604 episode to human activity. Tipping (2004) has suggested that the likelihood of

605 natural fire was arguably much higher during the Early Holocene. However, the

606 changes recorded in the Roughan pollen diagram (Figure 6a,b) do share similar

607 characteristics with woodland openings attributed to Mesolithic activity. Support for

608 disturbance to create areas of browse for wild animals is suggested by taxa often

609 linked with disturbance (e.g. Innes \& Blackford, 2003) from the pollen assemblage in

610 the burnt material. Evidence for herbivore grazing from the NPP record was less

611 forthcoming with only Sordaria-type (HdV-55A; Figure 7) present in trace amounts.

612 In the absence of red deer and other major herbivores, it has been suggested that

613 Mesolithic people in Ireland did not have a reason to maintain clearings (Woodman

614 et al., 1997). The primary target for any hunters would be wild pig (Woodman et al.,

615 1999): Pteridium is a favoured food of wild pigs (Grigson, 1982) and it features in the

616 latter part of LPAZs Rou1 and Rou2 (Figure 6b). Rumex and Pteridium often occur

617 naturally in woodlands and they would respond in increased numbers and wider

618 dispersal if the woodland canopy was more open (Tipping, 2004). Alternatively the

619 disturbance indicators simply could be responding to natural perturbations in and

620 around the palaeochannel system.

621 Evidence for Mesolithic burning is rarely recorded in pollen studies from

622 Northern Ireland, possibly because previous studies have not included microscopic

623 charcoal analysis as part of their study (e.g. Pilcher, 1973; Pilcher and Smith, 1979;

624 Smith and Goddard, 1991). Peaks in microscopic charcoal have been recorded at

625 Ballynahatty, Co. Down, and they were interpreted as a possible domestic fire as

626 there was no evidence for any detrimental impact on the woodland (Plunkett et al.,

627 2008). However, the presence of Late Mesolithic populations is well established from 
628 archaeological evidence (e.g. Bayliss and Woodman, 2009; Meiklejohn and

629 Woodman, 2012), in particular along the Bann River Valley (e.g. Mitchell, 1955;

630 Woodman, 1977, 1985; Spaulding et al., 1999), while finds of Mesolithic flints occur

631 in Co. Tyrone (Ivens and Simpson, 1988). The phase of burning at Roughan adds to

632 this body of evidence and it represents possibly the only Mesolithic archaeology

633 discovered along the new road corridor.

634

Late Neolithic/Early Bronze Age

\section{Environmental setting of the burnt mounds}

637 Pollen evidence from the Late Neolithic/Early Bronze Age phase of burnt mound use

638 (c. $2860 \mathrm{cal}$ yr BC to $2140 \mathrm{cal} \mathrm{yr} \mathrm{BC)} \mathrm{reveals} \mathrm{that} \mathrm{this} \mathrm{activity} \mathrm{took} \mathrm{place} \mathrm{in} \mathrm{a} \mathrm{landscape}$ 639 where mixed woodland and Alnus carr were both locally predominant (Figures 4 and 640 6). High pollen percentages of Alnus and Corylus derived from trees growing on both

641 floodplains places the burnt mounds at a fen carr-edge, where the pollen source 642 area could have been limited to anywhere between 50 and $>100$ m radius (Binney et 643 al., 2005; Bunting et al., 2005).

644 A decline in total arboreal pollen percentages at Ballygawley coincided with 645 the deposition of the burnt material. This possibly represents a short-lived phase of 646 woodland clearance associated with the use of the burnt mound. However, this

647 decrease might be artificial as the pollen content of the burnt material was

648 extremely low. Therefore counts will not be an accurate reflection of the local

649 vegetation. Moreover, arboreal pollen percentages recover to their original values

650 when the deposition of the burnt material ends at $93 \mathrm{~cm}$ (Figure 4). The radiocarbon 651 chronology is insufficient to firmly ascertain the impact of later burnt mound use in 
652 the local area. Assuming that that subsequent period of use is recorded in the peat

653 above burnt mound deposit, and notwithstanding the coarser sampling resolution,

654 the microfossil and microscopic charcoal records suggests that any impact was mute.

655 Microscopic charcoal values remained low and there were no major perturbations in

656 total arboreal pollen or for individual tree and shrub taxa. Non-arboreal pollen taxa

657 and coprophilous fungi commonly associated with human activity and disturbance

658 only occurred in trace amounts and sporadically. This suggests that the impact of

659 other burnt mounds close to the sampling site was not detected due the pollen

660 source area being spatially restricted (Figure $1 \mathrm{~b}$ ).

661

There was an apparent hiatus in the Roughan archaeological record between

662 the Mesolithic and the latter half of the third millennium BC. The coarse resolution

663 of the pollen diagram in LPAZ Rou3 hinders any attempt to identify any human

664 impact (Figure 6a,b). Radiocarbon dates from a stone spread [8502], a burnt spread

665 [8467] and a burnt mound [8422] (Supplementary Figure 3) provide the next

666 definitive evidence for human activity at Roughan c. 2870 cal yr BC. Notwithstanding

667 the crude chronology and slow sediment accumulation rate between 43 and $18 \mathrm{~cm}$,

668 this phase of activity tentatively correlates with around $21 \mathrm{~cm}$ in the pollen diagram.

669 This is slightly later than the resumption of the see-saw pattern in the arboreal

670 pollen and the increase and/or regular presence of pollen taxa and NPPS often

671 associated with human activity (Figures $6 a, b$ and 7). Microscopic charcoal values also

672 increased during this time. Until the chronology is improved it is unclear as to

673 whether this represents human presence before the burnt mounds were used.

674 Notwithstanding this, the evidence for human activity is still relatively mute given

675 the close proximity of the burnt mounds. 

records at both sites which appear to be associated with the burnt material. These trends are discussed further below.

681 Regular fluctuations in the pollen values of tree and shrub taxa have been recorded 682 prior to and following the burnt spread and mounds recorded in the two monoliths.

683 The exact reason for what we describe as the 'see-saw' pattern is unknown. In

684 particular these peaks and troughs are recorded in the pollen curves of Quercus and 685 Corylus avellana-type at Ballygawley and Pinus, Ulmus, Salix, and to a lesser extent, 686 Alnus, Quercus and Corylus avellana-type at Roughan (Figures 3 and 5). The high 687 values of both Alnus and Corylus avellana-type pollen infer that these tree types 688 were growing near to the burnt mound sites (Brown, 1999; Waller et al., 2005). The 689 macroscopic charcoal records suggest that they were used for fuelwood (Figures 8 690 and 9). In order to determine if the see-saw pattern was real rather than an artefact 692 of expressing the pollen data as percentages, and to negate the effect of the 693 abundance of one pollen type depressing the value of others (Simmons \& Innes, 694 1988), concentrations were also calculated. Pollen concentrations for major taxa 695 from Ballygawley and Roughan are shown in Supplementary Figures 4, 5a and b. 696 With the exception of some minor differences, they show a consistent pattern which 697 suggests that they have been influenced by changing sediment accumulation rates 698 and possible variations in pollen productivity. When the pollen concentrations are 699 normalised against the total pollen concentrations (excluding each taxon), the see- 
saw pattern is clearly seen (Supplementary Figure 4c-e). This suggests that the see-

saw pattern observed reflects real changes in the vegetation. The normalised pollen concentrations patterns are in good agreement with the percentage data for each taxon. Such see-saw patterning in pollen diagrams is enigmatic. The patterns could be the result of several processes including woodland management, natural fluctuations or taphonomic processes. A discussion of each of these possibilities

706 follows:

\section{Human activity}

The see-saw pattern seen in the pollen data infers that some form of management may have been practised to maintain local woodland availability. This might have been inadvertent assuming there were sufficient trees available to provide a continuous supply of wood fuel for the burnt mounds or through deliberate coppicing and/or pollarding. Rackham (2005) also observes that trees such as Corylus avellana are best coppiced on a short rotation cycle so that the wood can be easily worked. Thus, if the hot stone technology associated with the burnt mounds required a significant volume of wood fuel, the use of fairly intensive coppicing (4-7

717 years) may have been required in order to resource this activity without completely 718 removing areas of woodland. Attempts to recognise episodes of coppicing within pollen diagrams have met 720 with limited success (e.g. Waller and Schofield, 2007). Waller et al. (2012) also found

721 it difficult to identify cutting cycles and growth responses within pollen diagrams.

722 Using a modelled scenario of coppice within Alnus glutinosa carr on a 20-year

723 rotation, Waller et al. (2012) showed a shift in pollen productivity (declining $A$. 
724 glutinosa and increasing C. avellana). This scenario might explain the inverse

725 relationship between these taxa in the pollen record at Roughan. Despite being

726 dominant species in the charcoal record (Figure 8) Alnus does not demonstrate a

727 see-saw pattern at Ballygawley. If this species was managed, any rotation or

728 management markers could not be identified in the pollen record.

729 Corylus avellana-type is the second most and most abundant type of charcoal

730 recovered from the burnt mounds (Figures 8 and 9). Its exploitation may explain the

731 see-saw pattern in the pollen percentage and concentration data (Figures 4, 6,

732 Supplementary Figures 4 and 5). However, the known rotation patterns described

733 above (6-20 years) are probably much shorter than the see-saw pattern observed in

734 the pollen records here. The pollen data are constrained by a limited chronology

735 and the time span encapsulated in a $0.5 \mathrm{~cm}$ thick sample is unknown.

736 Quercus and Betula are also common in the Roughan macroscopic charcoal

737 assemblages. At Llwyn Du, northwest Wales, a see-saw pattern for both taxa was

738 reconstructed from fine resolution pollen data during iron production at a medieval

739 bloomery. Crew and Mighall (2013) argued that the pattern was probably caused by

740 woodland management of oak and birch. Wheeler $(2007,2011)$ also observed

741 correlating see-saw patterns at Rievaulx and Bilsdale in North Yorkshire. Wickham et

742 al. (2010) observed that short rotation coppicing (2-3 years) of willow can lead to a

743 higher wood yield which may explain the see-saw pattern in the Salix pollen record

744 at Roughan, although Salix wood was only recovered in small quantities (Figure 11).

745 Corylus, Quercus and Alnus charcoal is commonly recovered from burnt

746 mounds (Stuijts, 2005; O'Donnell, 2007, 2009; Miller and Ramsey, 2009). The

747 differences in the frequency of trees from site to site may also reflect changes in the 
749 preferential selection.

750 Growth ring curvature of the charcoal fragments indicates that the majority

751 of the fuel wood was derived from small to medium-sized wood such as twigs,

752 branch wood and possibly rods/stemwood. These sizes might indicate the deliberate

753 collection through coppicing and/or pollarding (Boyd, 1988). Larger pieces of wood

754 were also used, probably trunk wood, suggested by charcoal fragments displaying

755 weakly curved growth rings (Marguerie and Hunot, 2007). At Ballygawley these

756 larger timbers are restricted to Corylus avellana, Alnus glutinosa and Quercus sp.,

757 while at Roughan they include Betula sp., Salix sp. and Prunus avium suggesting

758 some deliberate selection or simply a wider availability.

759 The worked wood analysis of planks and wattle sails used in the construction

760 of troughs also suggest that some form of woodland management was practiced.

761 Wattle sails were mainly constructed from long straight hazel stems that had similar

762 ring counts (4-7 years) and diameter sizes (10-30 mm). This stemwood may have

763 been from coppiced or new growth cut within an interval of less than 10 years

764 (Bamforth et al., 2010).

765

$766 \quad$ Natural fluctuations and taphonomic processes

767 Other explanations may have also influenced the pattern of pollen percentages and 768 concentrations. Fluctuations in arboreal pollen assemblages are to be expected

769 within local Alnus carr-woodland, reflecting natural cycles of woodland in a

770 floodplain environment (Waller, 1998; Waller et al., 2005). These Alnus glutinosa-

771 dominated communities often exhibit small-scale heterogeneity due to the 
instability of the ground substrates and tree weight (Rodwell, 1991). Changes in the herbaceous pollen assemblage, mainly of Poaceae and Cyperaceae pollen, also may indicate some opening of the local carr and increased presence of fen-reedswamp.

\section{ii) Increases across the cross-fraction micro-charcoal}

There is a cross-fraction increase in microscopic charcoal values during burnt mound activity (Figures 5 and 6). These elevated charcoal levels are expected given the nature of the hot stone technology and large quantities of macroscopic charcoal present. This is particularly evident in the $>50 \mu \mathrm{m}$ size class, signifying the intensification of local on-site burning.

\section{iii) Greater presence of wood detritus}

An increase in probable dead wood indicators, SPPs (HdV-114) and Sordaria-type (HdV-55A) (van Geel et al., 1983, 2003) in levels associated with burnt mound deposits occurred at both sites. $K$. deusta (HdV-44) was also present at Roughan and HdV-72D also feeds off vegetation debris. It is likely that the SPPs represented a combination of decomposed Corylus avellana, Alnus glutinosa and Betula sp. remains (Schweingruber, 1990). Chopping and/or storing of wood fuel may have occurred near to the burnt mounds with fungi (e.g. Sordaria sp.) attacking stored wood (Feist et al., 1973). Fungal hyphae were observed within macroscopic charcoal fragments, which could also represent the use of deadwood for fuel (Marguerie and Hunot, 2007) or simply woody debris derived from the catchment. There is no evidence of working debris from the waterlogged wood recovered from Ballygawley. Wood may have been fashioned prior to being brought to site to line the troughs. 
797

798 scrapers were present within the finds assemblage (Lochrie, 2010b).

799

800

increase in SPPs indicative of detritus may be related to bark stripping. Stone

\section{iv) Presence of herbivores and cereal cultivation}

It appears that burnt mound activity is strongly associated with a pastoral economy. Coprophilous fungal spores occur in both assemblages suggests that animals were present locally. Cugny et al. (2010) consider Cercophora-type (HdV-112) to be a reliable dung indicator. Evidence for pasture is strong in the pollen records and the discovery of burnt bone has indicated that animal butchery was taking place at Ballygawley (Tourunen, 2009). Such activity has also been advocated for other burnt mound sites in Ireland (Tourunen, 2008).

Evidence for cereal cultivation is less forthcoming. Only one Triticum-type was recorded at Ballygawley and it is not associated with the burnt mound. Poaceae grains (>35 $\mu \mathrm{m}$ in diameter) were recorded at both sites. However, these could be wild grasses such as Glyceria and Elytrigia (Stace, 2001; Tweddle et al., 2005). Moreover, the poor dispersal ability of large grasses and cereal pollen, combined with relatively dense woodland, might have dampened any cultivation signal in the pollen record (Vuorela, 1973; Tweddle et al., 2005).

\section{v) Increased levels of eutrophy and peaks in Sphagnum}

Sphagnum peaks occur during the phase of burnt mound use and could be related to the use of bogmoss in the lining of troughs. Increased levels of meso- or eutrophy were also implied by Diportheca rhizophila (HdV-143), HdV-62, HdV-128 and possibly 
820 HdV-55A at Roughan (Pals et al., 1980; van Geel et al., 1983). This could be the result

821 of water either used in the troughs, pooling during periods of non-activity, or from

822 stagnant water lying close by. In contrast, high amounts of Gloeotrichia-type (HdV-

$823146)$ are indicative of nutrient poor conditions.

824

825 CONCLUSIONS

826 The results of this study suggest that burnt spread and mound activity can be

827 characterised in the following way:

828 1. Activity appears to have had a small non-permanent impact on the local

829 environment during the Mesolithic, Late Neolithic and Bronze Age. The spatial

830 impact of such activity appears to have been restricted but needs to be constrained

831 by multiple pollen profiles and more robust chronologies for the

832 palaeoenvironmental deposits.

833 2. Activity took place at water side locations in small clearings with pasture close by,

834 as suggested by the occurrence of herbs associated with pasture and the regular

835 presence of coprophilous fungi. However, despite the wealth of local activity

836 especially from the Late Neolithic onwards, the occurrence of non-arboreal pollen

837 taxa associated with human activity is generally limited to trace amounts. This might

838 be due to taphonomic effects including a limited pollen source area and/or pollen

839 filtering by high arboreal pollen producers and relatively dense woodland. Natural

840 perturbations in a floodplain environment could also account for some of the

841 changes recorded.

842 3. Burnt mound use appears to be associated more with local pasture rather than

843 cereal cultivation. Cereal-type pollen only occurred in trace amounts and then only 
844 sporadically in the pollen records. Although not conclusive, evidence for animal

845 butchery and pasture point towards cooking as the most likely activity.

846 4. Each burnt mound deposit/burnt spread was associated with specific changes in

847 the pollen, NPPs and microscopic charcoal records, irrespective of the age of the

848 burnt material. These included a repetitive see-saw pattern in the pollen

849 percentages and concentrations of major trees, shrubs and herbs, high microscopic

850 charcoal values, presence of coprophilous fungi, peaks in Gloeotrichia-type (HdV-

851 146), SPPs (HdV-114) and peaks in Sphagnum. Whether these are indicative of burnt

852 mound use is unclear but possible.

853 5. It is reasonable to suggest that: (a) charcoal is associated with fuelwood and

854 repetitive exploitation of wood for fuel (e.g. deliberate cyclical coppicing) is known in

855 prehistory (Rasmussen, 1990) which could be implied in the context of the burnt

856 mounds at Ballygawley and Roughan; (b) increases in SPPs (HdV-114) and Sordaria-

857 type (HdV-55A) may represent detritus from possible wood preparation (e.g.

858 chopping/leaf stripping/bark removal etc.) which may have been taken from trees

859 that were naturally present in the floodplain environment; (c) Sphagnum was used

860 to line and seal the troughs; and (d), burnt mound activity changed water conditions

861 leaving them eu- to mesotrophic. These markers may be diagnostic indictors of burnt

862 mound use in the palaeoecological record but this hypothesis now requires further

863 testing.

864

865 Although the results of this study provide little direct insight into the function of

866 burnt mounds, they do provide us with a greater understanding of human- 

would provide useful information.

869

Road services Northern Ireland, Jacobs and Headland Archaeology funded this project. Thanks to

871 Audrey Innes for the pollen preparations, Alison Sandison and Jenny Johnston for drafting the figures.

872 Eddie Bailey (Headland Archaeology Ltd.) for kindly providing site information and illustrations. J.E.

873 Schofield kindly commented upon an earlier draft of the manuscript. Caroline Norman at Headland

874 Archaeology kindly provided some of the illustrations. Two anonymous reviewers and Jamie

875 Woodwood provided useful comments that helped to improve the paper. Thanks are also due to

876 Roads Ireland, Jacobs, the Department for Regional Development, Mouchel Parkman and John Cronin

877 Associates.

878

879 REFERENCES

880 Anderson, E., Harrison, S., Passmore, D., \& Mighall, T.M. (2000). Holocene alluvial fan

881 development in the MacGillycuddy's Reeks, south-west Ireland. Bulletin of the

882 Geological Society of America, 112, 1834-1849.

883

884 Anthony, I.M.C., Sanderson, D.C.W., Cook, G.T., Abernethy, D., \& Housley, R.A.

885 (2001). Dating a burnt mound from Kilmartin, Argyll, Scotland. Quaternary Science

886 Reviews, 20, 921-925.

888 Asouti, E. (2001). Charcoal analysis from Çatalhöyük and Pinarbaşi, two Neolithic

889 sites in the Konya Plain, south-central Anatolia, Turkey. Unpublished doctoral thesis, 890 University College London. 
893 of the A4/A5 Road Improvement Scheme. Unpublished Report. Edinburgh: Headland 894 Archaeology Ltd.

895

896 Bailey, E. (2010b). Archaeological Excavations at Roughan, Co. Tyrone in advance of 897 the A4/A5 Road Improvement Scheme. Unpublished Report. Edinburgh: Headland 898 Archaeology Ltd.

899

900 Bamforth, M., Gray L., \& Taylor, M. (2010). Waterlogged wood analysis report;

901 A4/A5 corridor improvements (Dungannon-Ballygawley). Unpublished Client Report.

902 Chester: L-P Archaeology.

903

904 Barber, K.E. (1976). History of vegetation. In S.B. Chapman (Ed.) Methods in plant 905 ecology, (pp. 5-83). Oxford: Blackwell.

906

907 Barfield, L., \& Hodder, M. (1987). Burnt mounds as saunas and the prehistory of 908 bathing. Antiquity, 61, 370-379.

909

910 Bartley, D. D., \& Chambers, C. (1992). A pollen diagram, radiocarbon ages and

911 evidence of agriculture on Extwistle Moor, Lancashire. New Phytologist, 121, 311912320.

914 Bayliss, A., McAvoy, F., \& Whittle, A. (2007). The world recreated: redating Silbury

915 Hill in its monumental landscape. Antiquity, 81, 26-53. 
917 Bayliss, A., \& Woodman, P.C. (2009). A new Bayesian chronology for Mesolithic

918 occupation at Mount Sandel, Northern Ireland. Proceedings of the Prehistoric

919 Society, 75, 101-123.

920

921 Benninghoff, W.S. (1962). Calculation of pollen and spore density in sediments by

922 addition of exotic pollen in known quantities. Pollen et Spores, 4, 332-333.

924 Beug, H-J. (2004). Leitfaden der pollenbestimmung für mitteleuropa und

925 angrenzende gebiete. München: Verlag Dr. Friedrich Pfeil.

926

Bigman, D. P., \& Lanzarone, P. M. (2014). Investigating Construction History, Labour Investment and Social Change at Ocmulgee National Monument's Mound A, Georgia, USA, Using Ground-penetrating Radar. Archaeological Prospection, 21, 213-224. vegetation. Review of Palaeobotany and Palynology, 134, 197-218. sequences. Quaternary Geochronology, 5, 512-518.

938 Bradley, R. (1978). The prehistoric settlement of the British Isles. London: Routledge 939 \& Kegan Paul. 
941 Brindley, A. L., Lanting, J. N., \& Mook, W. G. (1989). Radiocarbon dates from Irish

942 fulachta fiadh and other burnt mounds. The Journal of Irish Archaeology, 5, 25-33.

943

944 Brock, F., Lee, S., Housley, R. A., \& Ramsey, C. B. (2011). Variation in the radiocarbon

945 age of different fractions of peat: a case study from Ahrenshöft, northern Germany.

946 Quaternary Geochronology, 6, 550-555.

947

948 Bronk Ramsey, C. (2009a). OxCal 4.1. OxCal Project. Oxford: University of Oxford.

950 Bronk Ramsey, C. (2009b). Bayesian analysis of radiocarbon dates. Radiocarbon, 51, $951 \quad 337-360$.

953 Brown, A.G. (1999). Biodiversity and pollen analysis: modern pollen studies and the 954 recent history of a floodplain woodland in S.W. Ireland. Journal of Biogeography, 26, $955 \quad 19-32$.

956

957 Brown A.G., Carpenter, R.G., \& Walling, D.E. (2007). Monitoring fluvial pollen

958 transport, its relationship to catchment vegetation and implications for

959 palaeoenvironmental studies. Review of Palaeobotany and Palynology, 147, 60-76.

960

961 Boyd, W.E. (1988). Methodological problems in the analysis of fossil non-artifactual

962 wood assemblages from archaeological sites. Journal Archaeological Science, 15, $963 \quad 603-619$. 
965 Buckley, V. (1990). Burnt offerings: International contributions to burnt mound 966 archaeology. Dublin: Wordwell Ltd Academic Publications.

967

968 Bunting, M.J., Armitage, R., Binney, H.A., \& Waller M. (2005). Estimates of 'relative 969 pollen productivity' and 'relevant source area of pollen' for major tree taxa in two 970 Norfolk (UK) woodlands. The Holocene, 15, 459-465.

971

972 Chambers, F. M. (1993). Climate change and human impact on the landscape:

973 studies in palaeoecology and environmental archaeology. London: Chapman and 974 Hall.

975

976 Chapman, H.P. and Gearey, B.R. (2013). Modelling Archaeology and

977 Palaeoenvironments in Wetlands: The Hidden Landscape Archaeology of Hatfield 978 and Thorne Moors. Oxford, Oxbow.

979

980 Coon, N. (1978). The dictionary of useful plants: The use, history, and folklore of 981 more than 500 plant species. Market Harborough: Rodale Press.

982

983 Crew, P., \& Mighall, T.M. (2013). The fuel supply and woodland management at a $98414^{\text {th }}$ century bloomery in Snowdonia, a multi-disciplinary approach. In J. Humphris, 985 \& T. Rehren (Eds.), The World of Iron (pp. 473-482). London: Archetype Publications. 986 

Eerkens, J. W., DeGeorgey, A., Spero, H. J., \& Descantes, C. (2014). Seasonality of

Cugny, C., Mazier, F., \& Galop, D. (2010). Modern and fossil non-pollen palynomorphs from the Basque mountains (western Pyrenees, France): the use of coprophilous fungi to reconstruct pastoral activity. Vegetation History and Archaeobotany, 19, 391-408.

Delcourt P.A.,\& Delcourt H.R. (1980). Pollen preservation and environmental history in the south-eastern United States. Palynology, 4, 215-321.

Dickson, C. (1988). Distinguishing cereal from wild grass pollen: some limitations. Circaea, 5, 67-71.

Dimbleby, G.W. (1985). The Palynology of Archaeological Sites. London: Academic Press Inc.

Edwards, K.J. (1981). The separation of Corylus and Myrica pollen in modern and fossil samples. Pollen et Spores, 23, 205-218.

Edwards, K.J., \& Borthwick, D.M. (2010). The pollen content of so-called "ancient" field systems in Suðuroy, Faroe Islands, and the question of cereal cultivation. In S.A. Bengtson (Eds.), Dorete - her book - being a tribute to Dorete Bloch and to Faroese nature (pp. 96-116). Torshavn: Faroe University Press.

Late Prehistoric Clamming on San Francisco Bay: Oxygen Isotope Analyses of 
$1012 \quad 23-46$.

1013

1014 Fægri K., Iversen J., Kaland P.E., \& Krzywinski K. (1989). Textbook of Pollen Analysis.

1015 London: Blackwell.

1016

1017 Feehan, J. (1991). Fulachta fiadh in the South Midlands. Tipperary Historical Journal, $1018 \quad 4,202-207$.

1019

1020 Feist, W.C., Springer, E.L., \& Hajny, G.J. (1973). Spontaneous heating in piled wood

1021 chips - contribution of bacteria. Tappi, 56, 148-151.

1022

1023 Gonzalez, S., Innes, J.B., Huddart, D., Davey, P.J. \& Plater, A.J. (2000). Holocene

1024 coastal change in the north of the Isle of Man: stratigraphy, palaeoenvironment and

1025 archaeological evidence. In K. Pye, \& J. Allen (eds.) Coastal and Estuarine

1026 Environments: Sedimentology, Geomorphology and Geoarchaeology, (pp. 343-363)

1027 London: Geological Society Special Publication No. 175.

1028

1029 Gowen, M., Ó Néill, J., \& Philips, M. (2005).The Lisheen Mine Archaeological Project 1030 1996-8. Bray: Wordwell.

1032 Grigson, C. (1982). Porridge and pannage: pig husbandry in Neolithic England. In: M.

1033 Bell \& S. Limbrey (Eds.), Archaeological aspects of woodland ecology (pp 297-314).

1034 British Archaeological Report International Series 146. Oxford: Archaeopress. 
1036 Grimm, E.C. (1987). CONISS: A Fortran 77 program for stratigraphically constrained

1037 cluster analysis by the method of incremental sum of squares. Computers and

1038 Geosciences 13, 13-35.

1039

1040 Grimm, E.C. (2004). TGView 2.0.2. Illinois: Illinois State Museum.

1041

1042 Hather, J.G. (2000). The identification of the Northern European Woods: A guide for

1043 archaeologists and conservators. London: Archetype Publications.

1044

1045 Havinga, A.J. (1967). Palynology and pollen preservation. Review of Palaeobotany

1046 and Palynology, 2, 84-98.

1047

1048 Hawkes, A. (2013). The beginnings and evolution of the fulucht fiadh tradition in

1049 early prehistoric Ireland. Proceedings of the Royal Irish Academy, 114C, 1-51.

1050

1051 Huntley, B. (1993). Rapid early-Holocene migration and high abundance of hazel

1052 (Corylus avellana L.): alternative hypotheses (pp 205-215). In F.M. Chambers (ed.),

1053 Climate change and human impact on the landscape. London: Chapman and Hall.

1054

1055 Innes, J.B. (1998). The pollen analysis. In P. Topping, The excavation of burnt mounds

1056 at Titlington Mount, north Northumberland. Northern Archaeology, 15/16, 3-25.

1057 
1058

1059

1060

1061

1062

1063

1064

1065

1066

1067

1068

1069

1070

1071

1072

1073

1074

1075 Kołaczek, P., Zubek, S., Błaszkowski, J., Mleczko, P., \& Margielewski, W. (2013).

1076 Erosion or plant succession - How to interpret the presence of arbuscular

1077 mycorrhizal fungi (Glomeromycota) spores in pollen profiles collected from mires.

1078 Review of Palaeobotany and Palynology, 189, 29-37.

1079

1080 Kuhry, P. (1985). Transgression of a raised bog across a cover sand ridge originally

1081 covered with an oak-lime forest. Palaeoecological study of a Middle Holocene local 
1082

1083

1084

1085

1086

1087

1088

1089

1090

1091

1092

1093

1094

1095

1096

1097 at Ballygawley, Co. Tyrone in advance of the A4/A5 Road Improvement Scheme.

1098 Unpublished Report. Edinburgh: Headland Archaeology Ltd.

1099

1100 Lochrie, J. (2010b). Lithics (pp. 44-58). In E. Bailey (Ed.) Archaeological Excavations at

1101 Ballygawley, Co. Tyrone in advance of the A4/A5 Road Improvement Scheme.

1102

Unpublished Report. Edinburgh: Headland Archaeology Ltd. 
1104 Lochrie, J. (2010c). Worked Bone (pp. 58-60). In E. Bailey (Ed.), Archaeological

1105 Excavations at Ballygawley, Co. Tyrone in advance of the A4/A5 Road Improvement

1106 Scheme. Unpublished Report. Edinburgh: Headland Archaeology Ltd.

1107

1108 Lombardo, U., \& Prümers, H. (2010). Pre-Columbian human occupation patterns in

1109 the eastern plains of the Llanos de Moxos, Bolivian Amazonia. Journal of

1110 Archaeological Science, 37, 1875-1885.

1111

1112 Ludemann, T. (2009). Past fuel wood exploitation and natural forest vegetation in

1113 the Black Forest, the Vosges and neighbouring regions in western Central Europe.

1114 Palaeogeography, Palaeoclimatology, Palaeoecology 291, 154-156.

1115

1116 Ludemann, T., Michiels, H-G., \& Nöken, W. (2004). Spatial patterns of past wood

1117 exploitation, natural wood supply and growth conditions: indications of natural tree

1118 species distribution by anthracological studies of charcoal-burning remains.

1119 European Journal of Forest Research, 123, 283-292.

1120

1121 Marguerie D., \& Hunot J.Y. (2007). Charcoal analysis and dendrochronology: data

1122 from archaeological sites in north-western France. Journal of Archaeological Science,

$112334,1417-1433$.

1124

1125 Martin, P. S., \& Mehringer, P. J. (1965). Pleistocene pollen analysis and biogeography

1126 of the Southwest. na. 
1128 Meiklejohn C., \& Woodman P.C. (2012). Radiocarbon dating of Mesolithic human

1129 remains in Ireland. Mesolithic Miscellany, 22, 22-41.

1130

1131 Mighall, T.M., Timberlake, S., \& Crew, P. (2010). Vegetation changes in former

1132 mining and metalworking areas of Wales and Ireland during prehistoric and medieval

1133 times (pp. 19-26). In P. Belford, M. Palmer, M., \& R. White (Eds), Footprints of

1134 Industry. British Archaeological Reports British Series 523. Oxford: Archaeopress.

1135

1136 Mighall, T.M., Timpany, S., Blackford, J.J, Innes, J.B., O’Brien, C., O’Brien, W.F., \&

1137 Harrison, S. (2008). Vegetation changes during the Mesolithic and Neolithic in Co.

1138 Cork, SW Ireland. Vegetation History and Archaeobotany, 17, 617-628.

1139

1140 Miller, J., \& Ramsay, S. (2009). Botanical Evidence (pp. 27-29). In I. Banks, P.R.J.

1141 Duffy, G. MacGregor (Eds), Archaeology of landscape change in south-west Scotland,

11426000 BC -AD 1400: Excavations at William Grant and Sons Distillery, Girvan.

1143 Edinburgh: Society of Antiquaries of Scotland.

1144

1145 Mitchell, G.F. (1955). The Mesolithic Site at Toome Bay, Co. Londonderry. Studies in

1146 Irish Quaternary Deposits; No. 10. Ulster Journal of Archaeology, 18, 1-16.

1148 Monk, M. (2007). A greasy subject. Archaeology Ireland, 21, 22-24.

1150 Moore P.D., Webb J.A., \& Collinson, M.E. (1991). Pollen Analysis. Oxford: Blackwell 1151 Science. 
1153 Morgan, R.A. (1983). Tree-ring studies in the Somerset Levels: the examination of

1154 modern hazel growth in Bradfield Woods, Suffolk, and its implications for the

1155 prehistoric data. Somerset Levels Papers, 9, 44-48.

1156

1157 Nakagawa, T., Brugiapaglia, E., Digerfelt, G., Reille, M., de Beaulieu, J-L.,\& Yasuda, Y.

1158 (1998). Dense-media separation as a more efficient pollen extraction method for use

1159 with organic sediment/deposit samples: comparison with the conventional method.

1160 Boreas, 27, 15-24.

1161

1162 Nelle, O., Dreibrodt, S., \& Dannath, Y. 2010. Combining pollen and charcoal:

1163 evaluating Holocene vegetational composition and dynamics. Journal of

1164 Archaeological Science, 37, 2126-2135.

1165

1166 Newman, C., O’Connell, M., Dillon, M., \& Molloy, K. (2007). Interpretation of

1167 charcoal and pollen data relating to a late Iron Age ritual site in eastern Ireland: a

1168 holistic approach. Vegetation History and Archaeobotany, 16, 349-365.

1169

1170 O'Donnell, L. (2007). Environmental archaeology: Identifying patterns of exploitation

1171 in the Bronze Age, Charcoal and wood (pp. 27-65). In E. Grogan, L. O’Donnell, P.

1172 Johnston (Eds), The Bronze Age landscapes of the pipeline to the west. An integrated

1173 archaeological and environmental assessment. Bray: Wordwell Ltd. 
1175

1176

1177

1178 Ó Drisceóil, D. (1988). Burnt mounds: cooking or bathing? Antiquity, 62, 671-680.

O’Donnell, L. (2009). Charcoal analysis (pp. 113-124). In C. Baker (Ed.) The

Archaeology of Killeen Castle, Co. Meath. Bray: Wordwell Ltd.

1179

1180 O'Kelly, M.J. (1954). Excavations and experiments in ancient Irish cooking-places.

1181 Journal of the Antiquaries of Ireland, 84, 105-155.

1182

1183 Ó Néill, J. (2009). Burnt mounds in Northern and Western Europe: A study in

1184 prehistoric technology and society. Saarbrücken: VDM Verlag Dr. Müller.

1185

1186 O'Sullivan, M.,\& Downey, L. (2004). Fulachta fiadh. Archaeology Ireland, 17, 35-37.

1187

1188 Pals, J.P., van Geel, B., \& Delfos, A. (1980). Palaeoecological studies in the

1189 Klokkeweel bog near Hoogkarspel (Noord Holland). Review of Palaeobotany and

1190 Palynology, 30, 371-418.

1191

1192 Pilcher, J.R. (1973). Pollen analysis and radiocarbon dating of a peat on Slieve

1193 Gallion, Co. Tyrone, N. Ireland. New Phytologist, 72, 681-689.

1194

1195 Pilcher, J. R. (1991). Radiocarbon dating. Quaternary Dating Methods-A user's Guide.

1196 Quaternary Research Association Technical Guide, 4, 16-36. 
1198

1199 Neolithic and Bronze Age settlement in County Tyrone, Northern Ireland.

1200 Philosophical Transactions of the Royal Society, B, 286, 345-369.

1201

1202 Piotrowska, N., Blaauw, M., Mauquoy, D., \& Chambers, F. M. (2011). Constructing

1203

1204

1205

1206

1207

1208

1209

1210

1211 Plunkett, G., Carroll, F., Hartwell, B., Whitehouse, N.J., \& Reimer, P. (2008).

1212

1213

1214

1215 Prior, J. \& Alvin, K.L. (1983). Structural changes on charring woods of Dichrostachys

1216 and Salix from southern Africa. IAWA Bulletin, 4, 197-206.

1217

1218 Quinn B., \& Moore D. (2007). Ale, brewing and fulachta fiadh. Archaeology Ireland, $1219 \quad 21,8-11$.

1220

1221 Rackham, O. (2006). Woodlands. London: Harper Collins. 
1223 Rasmussen, P. (1990). Pollarding of trees in the Neolithic: Often presumed - Difficult

1224 to prove (pp. 77-99). In D.E. Robinson (Ed.) Experimentation and reconstruction in 1225 environmental archaeology. Oxford: Oxbow.

1226

1227 Reille, M. (1999). Pollen et spores d'Europe et d'Afrique du nord. Marseille:

1228 Laboratoire de Botanique Historique et Palynologie.

1230 Reimer, P.J., Baillie, M.G.L., Bard, E., Bayliss, A., Beck, J.W., Bertrand, C., Blackwell, 1231 P.G., Buck, C.E., Burr, G., Cutler, K.B., Damon, P.E., Edwards, R.L., Fairbanks, R.L., 1232 Freidrich, M., Guilderson, T.P., Hughen, K.A., Kromer, B., McCormac, F.G., Manning, 1233 S., Bronk Ramsey, C., Reimer, R.W., Remmele, S., Southon, J.R., Stuiver, M., Talamo, 1234 S., Taylor, F.W., van der Plicht, J., \& Weyhenmeyer, C.E. (2009). Quaternary Isotope 1235 Laboratory, Radiocarbon Calibration Program. Washington: University of 1236 Washington. http://radiocarbon.pa.qub.ac.uk/calib/calib.html

1238 Rodwell, J.S. (1991). British Plant Communities Volume 1: Woods and scrub.

1239 Cambridge: Cambridge University Press.

1241 Sayce, R. (1945). Canoes, coffins and cooking-troughs. Proceedings of the Society of 1242 Antiquaries of Scotland, 79, 106-111. 
1244 Schulte, E.E., \& Hopkins, B.G. (1996). Estimation of organic matter by weight loss-on-

1245 ignition. In F.R. Magdoff (Ed.), Soil organic matter: Analysis and interpretation

1246 (pp.21-31). Madison, WI: SSSA Special Publication 46.

1247

1248 Schweingruber, F.H. (1990). Microscopic Wood Anatomy. Birmensdorf: Eidgen-

1249 ssische Forschungsanstalt WSL.

1250

1251 Semple, S. (1998). A fear of the past: The place of the prehistoric burial mound in the

1252 ideology of middle and later Anglo-Saxon England. World Archaeology, 30, 109-126.

1253

1254 Shore, J. S., Bartley, D. D., \& Harkness, D. D. (1995). Problems encountered with the

125514 C dating of peat. Quaternary Science Reviews, 14, 373-383.

1256

1257 Simmons, I.G., \& Innes, J.B. (1988). Late Quaternary vegetational history of the North

1258 York Moors. IX. Numerical analysis and pollen concentration analysis of Flandrian II

1259 peat profiles from North Gill, Glaisdale Moor. Journal of Biogeography, 15, 273-297.

1260

1261 Simmons, I.G., \& Innes J.B. (1996). Disturbance Phases in the Mid-Holocene

1262 Vegetation at North Gill, North York Moors: Form and Process. Journal of

1263 Archaeological Science, 23, 183-191.

1264

1265 Smith, A.G., \& Goddard, I.C. (1991). A 12500 year record of vegetational history at

1266 Sluggan Bog, Co. Antrim, N. Ireland (incorporating a pollen zone scheme for the non-

1267 specialist). New Phytologist, 118, 167-187. 
1269 Spaulding, G.L., Moore, D.G, Barker, A., Bradle, M., Busby, A.B., Jones, K., Moseley,

1270 L., Patterson, P.E., Ravel, P., Scott, R., \& Skinner A. (1999). Lithic Material from the

1271 River Bann at Molloy's Ford, Glentone TD., Co. Londonderry. Ulster Journal of

1272 Archaeology, 58, 143-147.

1273

1274 Stace, C. (2001). New flora of the British Isles. Cambridge: Cambridge University 1275 Press.

1276

1277 Steadman, S. R. (2000). Spatial patterning and social complexity on prehistoric

1278 Anatolian tell sites: Models for mounds. Journal of Anthropological Archaeology, 19,

1279 164-199.

1280

1281 Stockmarr, J. (1971). Tablets with spores used in absolute pollen analysis. Pollen et Spores, 13, 615-621.

1283

1284 Stuijts, I. (2005). Wood and charcoal identification (pp. 137-186). In M. Gowen, J.O.,

1285 Neill, M. Philips (Eds.), The Lisheen Mine Archaeological Project 1996-8. Bray:

1286 Wordwell.

1287

1288 Stuijts, I. (2007). Wood and charcoal research in Ireland (pp. 179-93). In E.M. Murphy

1289 \& N.J. Whitehouse (Eds), Environmental Archaeology in Ireland. Oxford: Oxbow

1290 Books.

1291 
1292

1293

1294

1295

1296

1297

1298 Tipping, R. (2004). Interpretative issues concerning the driving forces of vegetation

1299 change in the Early Holocene of the British Isles (pp. 73-82). In A. Saville (Ed.),

1300 Mesolithic Scotland and its neighbours. Edinburgh: Society of Antiquaries of

1301 Scotland.

1302

1303 Tipping, R., Bunting, M.J, Davies, A.L., Murray, H., Fraser, S., \& McCulloch, R. (2009).

1304 Modelling land use around an early Neolithic timber 'hall' in north east Scotland

1305 from high spatial resolution pollen analyses. Journal of Archaeological Science, 36, $1306 \quad$ 140-149.

1307

1308

1309 the N9/N10 Carlow Bypass (pp. 37-44). In J. O'Sullivan, \& M. Stanley (Eds.), Roads,

1310 Rediscovery and Research Archaeology and the National Roads Authority

1311 Monograph Series No. 5. Dublin: National Roads Authority.

1312

1313 Tourunen, A. (2009). Final report on the faunal remains from Ballygawley (Site 1), Co.

1314 Tyrone. Unpublished Report. Edinburgh: Headland Archaeology Ltd. 
1316 Troels-Smith, J. (1955). Karakterisering af lose jordarter. Characterization of

1317 unconsolidated sediments. Geological Survey of Denmark IV. Series. Vol. 3 n. 10, pp

131873.

1319

1320 Tweddle, J. C., Edwards, K.J., \& Fieller, N.R.J. (2005). Multivariate statistical and

1321 other approaches for the separation of cereal from wild Poaceae pollen using a large

1322 Holocene dataset. Vegetation History and Archaeobotany, 14, 15-30.

1323

1324 van Geel, B. (1978). A palaeoecological study of Holocene peat bog sections in

1325 Germany and the Netherlands. Review of Palaeobotany and Palynology, 25, 1-120.

1326

1327 van Geel B. (2005). Non pollen palynomorphs. In J.P. Smol, H.J.B. Birks, W.M. Last

1328 (Eds), Tracking environmental change using lake sediments (pp.99-119). Kluwer

1329 Academic Publications, Dordrecht, pp.99-119.

1330

1331 Van Geel, B., Bos, J. M., \& Pals, J. P. (1983). Archaeological and palaeoecological

1332 aspects of a medieval house terp in a reclaimed raised bog area in North Holland.

1333 Ber. Rijksd. Oudheidk. Bodemonderz, 33, 419-444.

1334

1335 van Geel, B., Buurman, J., Brinkkemper, O., Schelvis, J., Aptroot, A., van Reenen, G.,

1336 \& Hakbijl T. (2003). Environmental reconstruction of a Roman Period settlement site

1337 in Uitgeest (The Netherlands), with special reference to coprophilous fungi. Journal

1338 of Archaeological Science, 30, 873-883.

1339 
van Geel, B., Hallewas, D.P.,\& Pals J.P. (1982/1983). A late Holocene deposit under

1341 the Westfriese Zeedijk near Enkhuizen (Prov. Of Noord-Holland, The Netherlands):

1342 palaeoecological and archaeological aspects. Review of Palaeobotany and

1343 Palynology, 38, 269-335.

1344

1345

1346 Vuorela, I. (1973). Relative pollen rain around cultivated fields. Acta Botanica

1347 Fennica, 102, 1-27.

1348

1349 Waller, M.P. (1998). An investigation into the palynological properties of fen peat

1350 through multiple pollen profiles from south-eastern England. Journal of

1351 Archaeological Science, 25, 631-642.

1352

1353 Waller, M.P., \& Schofield, J.E. (2007). Mid to Late Holocene vegetation and land use

1354 history in the Weald of south-eastern England: multiple pollen profiles from the Rye

1355 area. Vegetation History and Archaeobotany, 16, 367-384.

1356

1357 Waller, M.P., Grant, M.J., \& Bunting, M.J. (2012). Modern pollen studies from

1358 coppiced woodlands and their implications for the detection of woodland

1359 management in Holocene pollen records. Review of Palaeobotany and Palynology,

$1360 \quad 187,11-28$.

1361 
1362 Waller, M.P., Binney, H.A., Bunting, M.J., \& Armitage, R.A. (2005). The interpretation

1363 of fen carr pollen diagrams: pollen-vegetation relationships within the fen carr.

1364 Review of Palaeobotany and Palynology, 133, 179-202.

1365

1366 Wheeler, J. (2007). The implications of iron-working on the woodlands of Rievaulx

1367 and Bilsdale, North Yorkshire, United Kingdom: Historical, Palaeoecological and

1368 Palaeoenvironmental Perspectives circa 1068-2000. Unpublished PhD thesis,

1369 University of Bradford, Bradford.

1370

1371 Wheeler, J. (2011). Charcoal analysis of industrial fuelwood from medieval and early

1372 modern iron-working sites in Bilsdale and Rievaulx, North Yorkshire, UK: evidence for

1373 species selection and woodland management. Environmental Archaeology, 16, 15-

137435.

1375

1376 Whittington, G., \& Edwards, K.J. (1994). Palynology as a predictive tool in

1377 archaeology. Proceedings of the Society of Antiquities of Scotland, 124, 55-65.

1378

1379 Wickham, J., Rice, B., Finnan, J., \& McConnon, R. (2010). A review of past and current

1380 research on short rotation coppice in Ireland and abroad. Unpublished manuscript.

1381 Prepared for COFORD and Sustainable Energy Authority of Ireland.

1382

1383 Wilkins, B. (2011). Past orders: the archaeology of beer. Current Archaeology, 256,

$1384 \quad 28-35$.

1385 
1386

1387

1388

1389

1390

1391

1392

1393

1394

1395

1396

1397

1398

1399

1400

1401

1402

\section{Figure captions}

1404 Figure 1 Location of study sites (a) in Northern Ireland; (b) in Co Tyrone, Northern

1405 Ireland; (c) excavation site at Ballygawley showing the palaeochannels and burnt

1406 mounds (circles); (d) excavation site at Roughan showing Area C (e) the location of

1407 the monoliths and burnt mounds in Area C, Roughan.

1408 Figure 2 Stratigraphic sections for (a) Ballgawley; (b) Roughan; (c) Burnt mount

1409 context 8413 and the position of the Roughan monolith taken in this study. 
1410 Figure 3 Age depth graph for Roughan (smooth spline model) using Clam (Blaauw,

1411 2010)

1412 Figure 4a Percentage pollen diagram of trees, shrubs, dwarf shrubs and microscopic

1413 charcoal from Ballygawley, Co. Tyrone. Rare types are indicated by a cross (+), where

1414 one cross is equal to one pollen grain or NPP.

1415 Figure 4b Percentage pollen diagram of herbs from Ballygawley, Co. Tyrone. Rare

1416 types are indicated by a cross (+), where one cross is equal to one pollen grain or

1417 NPP.

1418 Figure 5 Percentage NPP diagram from Ballygawley, Co. Tyrone. Rare types are

1419 indicated by a cross $(+)$, where one cross is equal to one pollen grain or NPP.

1420 Figure 6a Percentage pollen diagram of trees, shrubs, dwarf shrubs and microscopic

1421 charcoal from Roughan, Co. Tyrone. Rare types are indicated by a cross (+), where

1422 one cross is equal to one pollen grain or NPP.

1423 Figure 6b Percentage pollen diagram of herbs from Roughan, Co. Tyrone. Rare types

1424 are indicated by a cross $(+)$, where one cross is equal to one pollen grain or NPP.

1425 Figure 7 Percentage NPP diagram from Roughan, Co. Tyrone. Rare types are

1426 indicated by a cross (+), where one cross is equal to one pollen grain or NPP.

1427 Figure 8 Charcoal identifications from Late Neolithic and Early Bronze Age Features

1428 at Ballygawley, Co. Tyrone.

1429 Figure 9 Charcoal identifications from Late Neolithic and Early Bronze Age Features

1430 at Roughan, Co. Tyrone.

1432 Supplementary Figure 1a. An example of a trough of the late Neolithic/Bronze Age

1433 found during this study at Ballgawley. 
1435 Supplementary Figure 1b. An example of a trough of the late Neolithic/Bronze Age

1436 found during this study at Ballgawley.

1438 Supplementary Figure 1c, d. Examples of the burnt mounds at Ballgawley.

1440 Supplementary Figure 2. Chronology of the archaeological features radiocarbon

1441 dated from Ballygawley, Co. Tyrone. Radiocarbon dates have been calibrated using

1442 OxCal 4.1 (Bronk Ramsey, 2009a) to 93.4\% probability using IntCal04 (Bronk Ramsey, 1443 2009b). All calibrated dates are referred to in calibrated years AD/BC.

1445 Supplementary Figure 3. Chronology of the archaeological features radiocarbon

1446 dated from Roughan, Co. Tyrone. Radiocarbon dates have been calibrated using

1447 OxCal 4.1 (Bronk Ramsey, 2009a) to 93.4\% probability using IntCal04 (Bronk Ramsey, 1448 2009b). All calibrated dates are referred to in calibrated years AD/BC.

1450 Supplementary Figure 4. Pollen concentrations for selected taxa from Ballygawley,

1451 Co. Tyrone. (a) total pollen concentrations; (b) Pollen concentrations for major taxa;

1452 (c) normalised pollen concentration ratio for Corylus and Cyperaceae; (d) normalised

1453 pollen concentration ratio for Quercus (Values between 94 and $102 \mathrm{~cm}$ were

1454 excluded as they were much higher than those data plotted in order to see the

1455 patterning either side of the burnt deposit. The pattern seen is not affected by their

1456 exclusion). Each taxon is expressed as ratio of individual taxon concentration divided

1457 by total pollen concentration minus the individual taxon (to avoid any effects derived 
1458 from auto correlation); (e) Normalised Poaceae concentration ratio; (f) Normalised 1459 Alnus concentration ratio.

1460

1461 Supplementary Figure 5a Pollen concentrations for selected taxa from Roughan, Co.

1462 Tyrone. (a) total pollen concentrations (dashed line for all graphs) and Corylus pollen

1463 concentrations (solid line); (b) Cyperaceae (solid line); (c) Alnus (solid line); (d)

1464 Quercus (solid line); (e) Salix (solid line); (f) Poaceae (solid line).

1465

1466 Supplementary Figure 5b Normalised pollen concentrations for selected taxa from

1467 Roughan, Co. Tyrone. Each taxon is expressed as ratio of individual taxon

1468 concentration divided by total pollen concentration minus the individual taxon (to

1469 avoid any effects derived from auto correlation). (a) Corylus; (b) Cyperaceae; (c)

1470 Alnus; (d) Quercus; (e) Salix; (f) Poaceae.

1471

1472 Table 1. Radiocarbon dates from the burnt mound monoliths (Ballygawley and

1473 Roughan).

1474

1475 Supplementary Table 1. Stratigraphical description of the monoliths used in this

1476 study.

1477

1478

1479

1480 

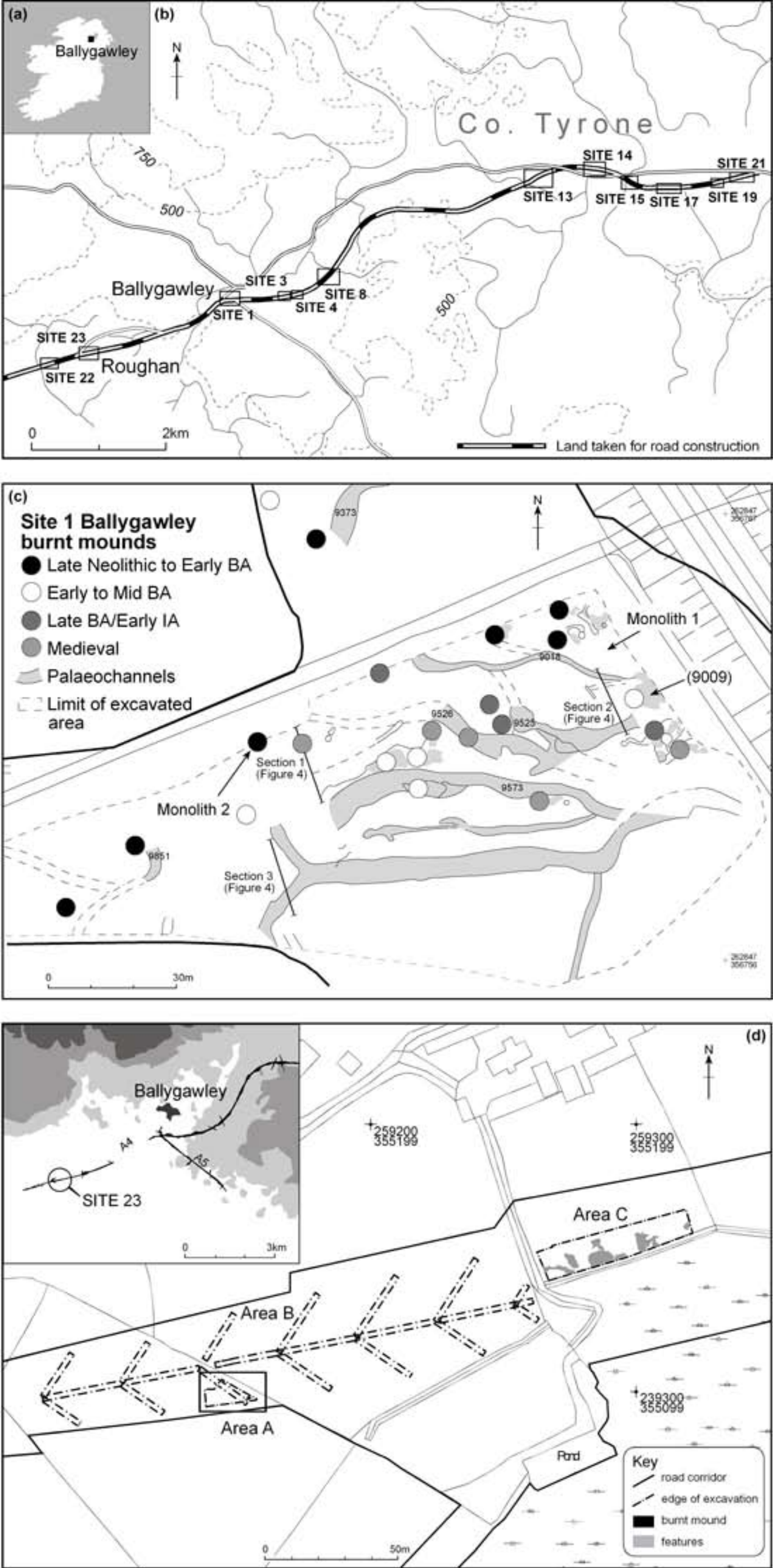



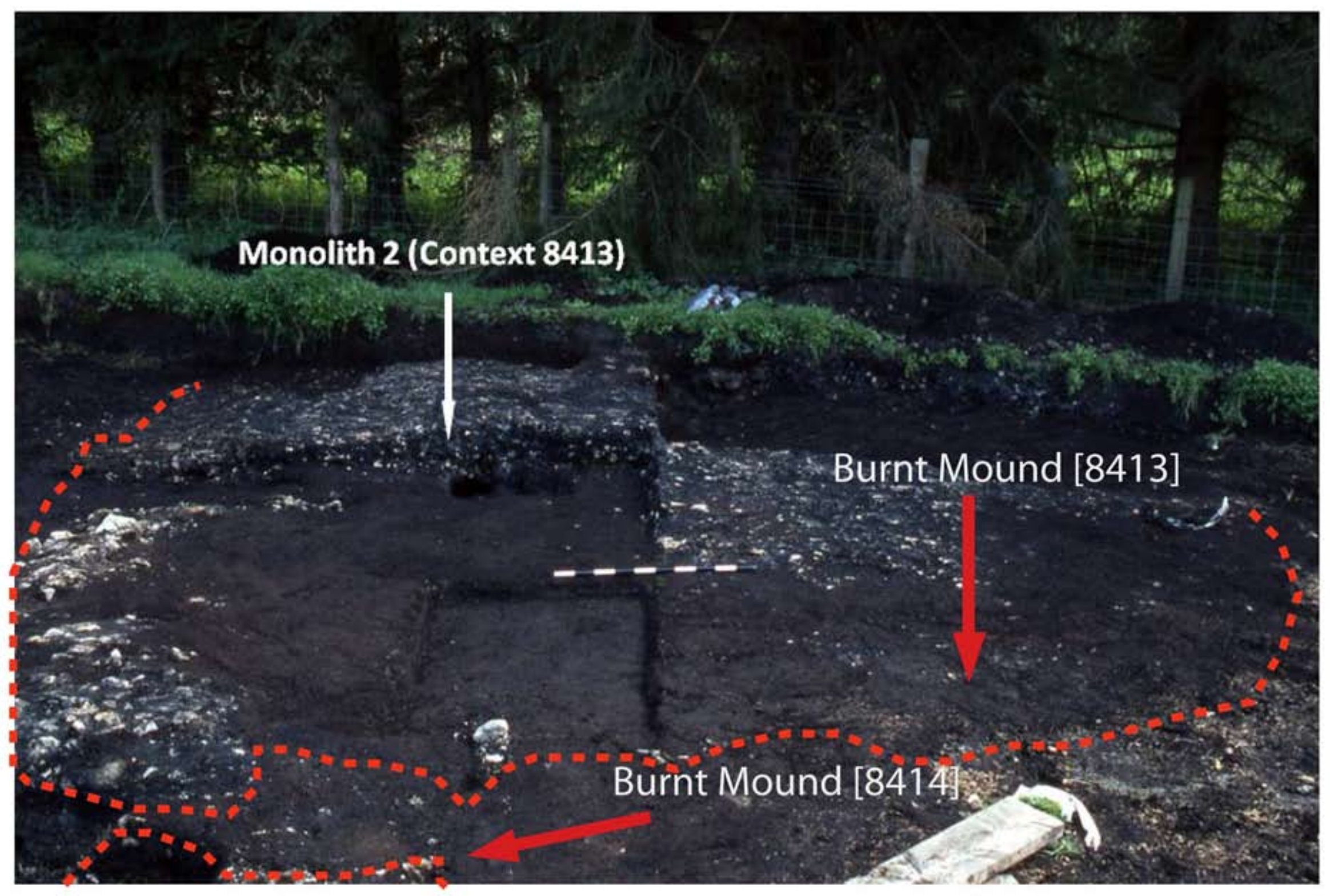




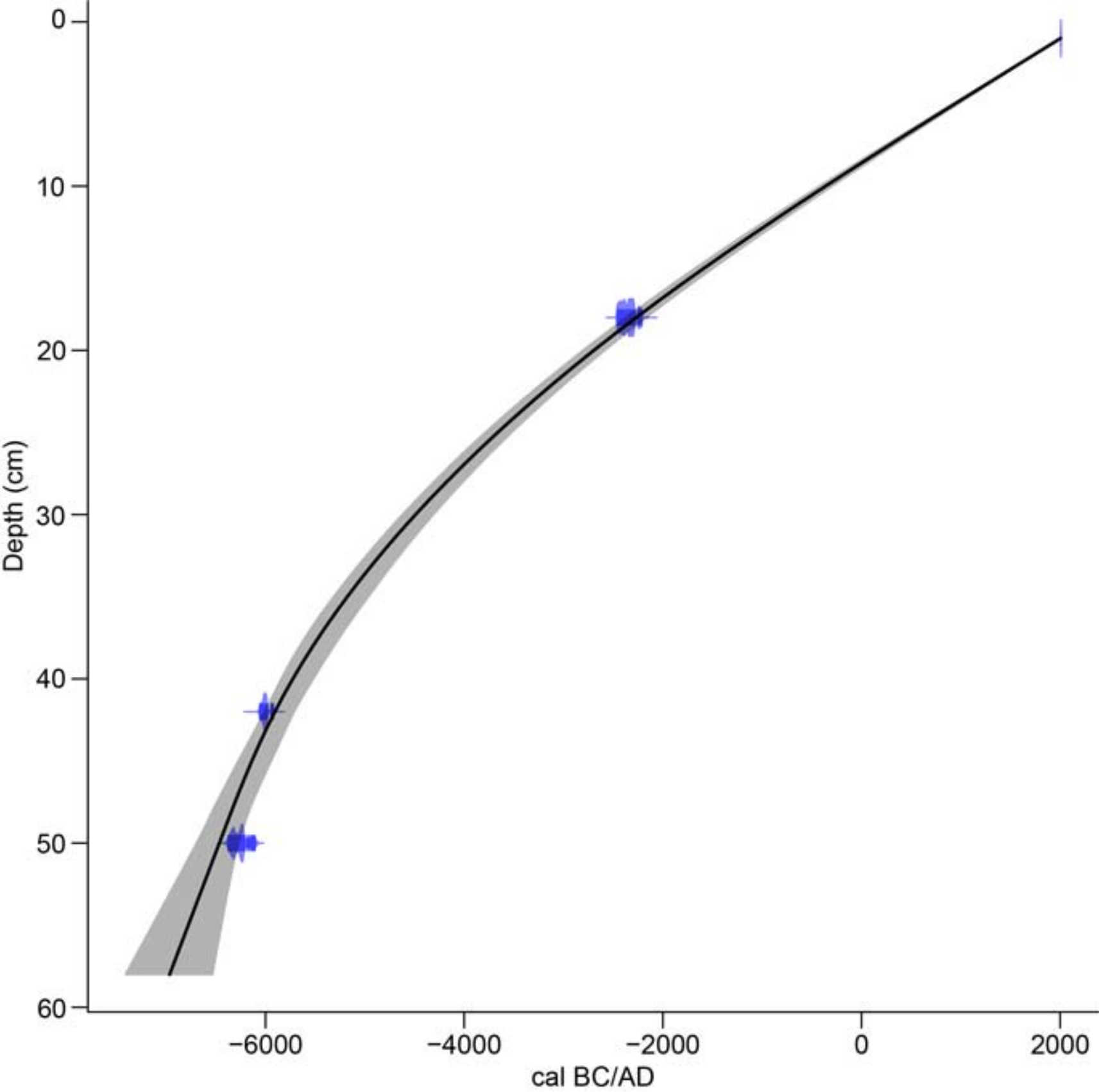




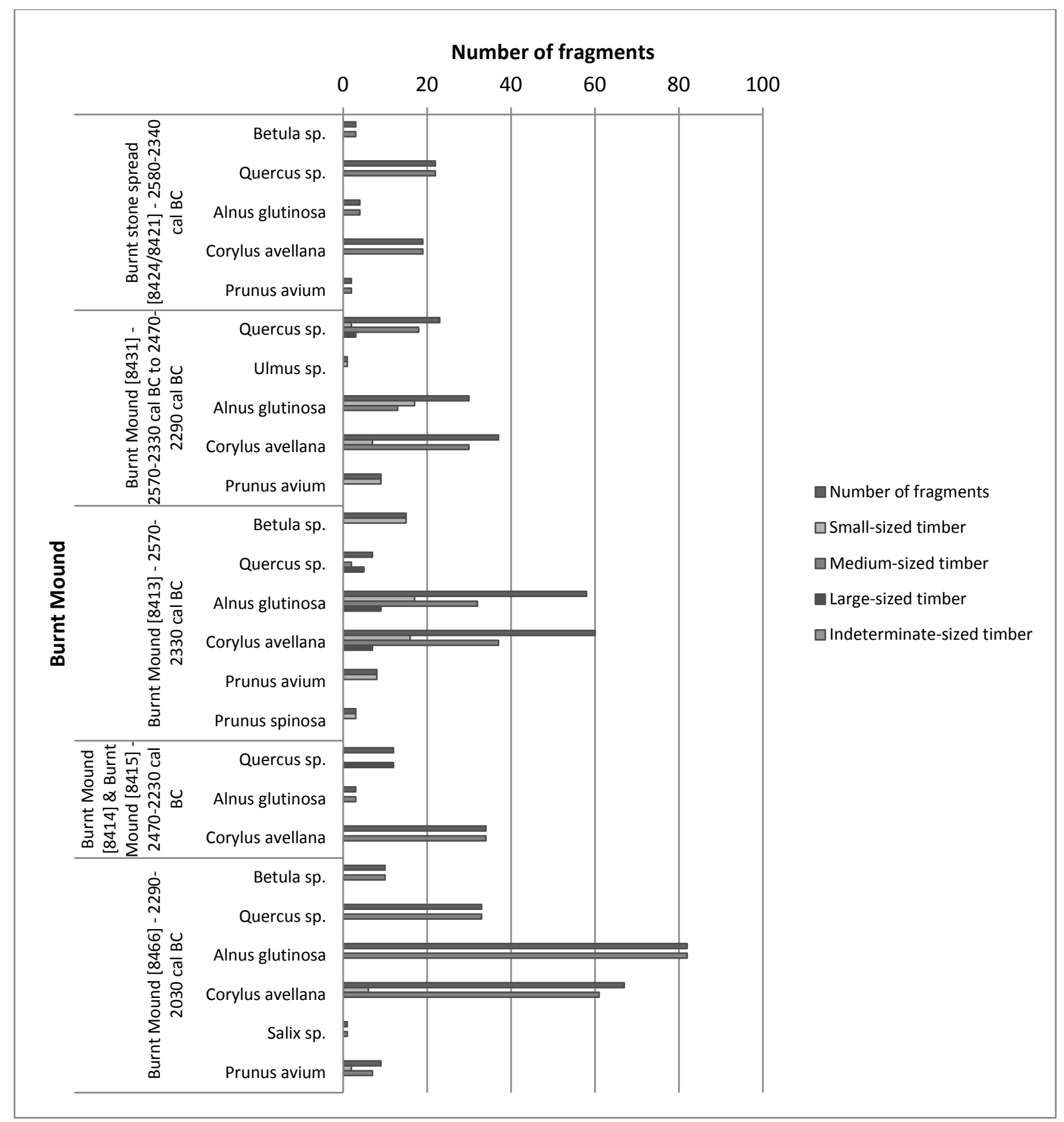




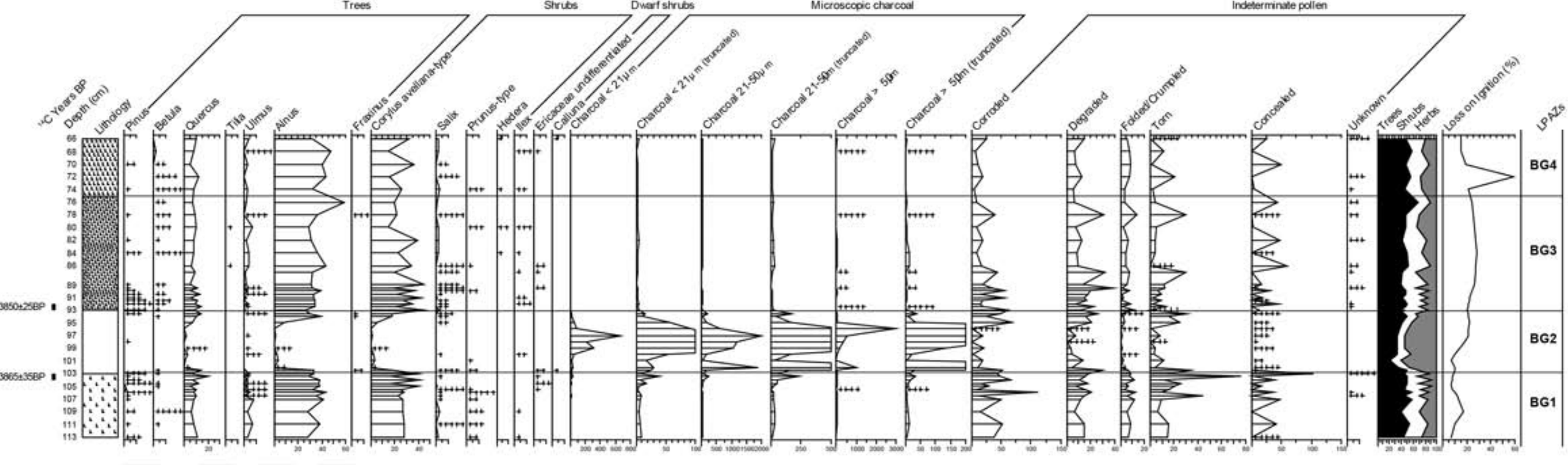

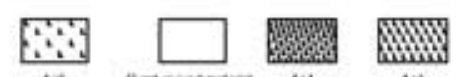




\section{Herbs}

Spores

$3850 \pm 25 \mathrm{BP}$$$
0^{\infty}
$$

5

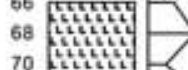

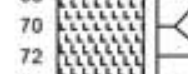

74
76
78
80
82
84

84

91
93
95

3865 35BP
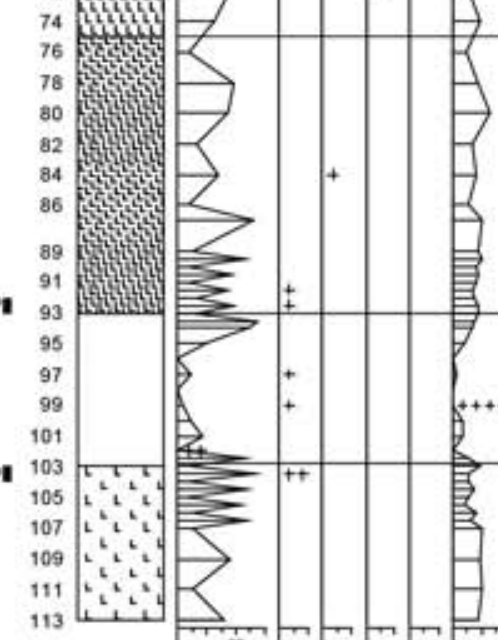

r.

(3)
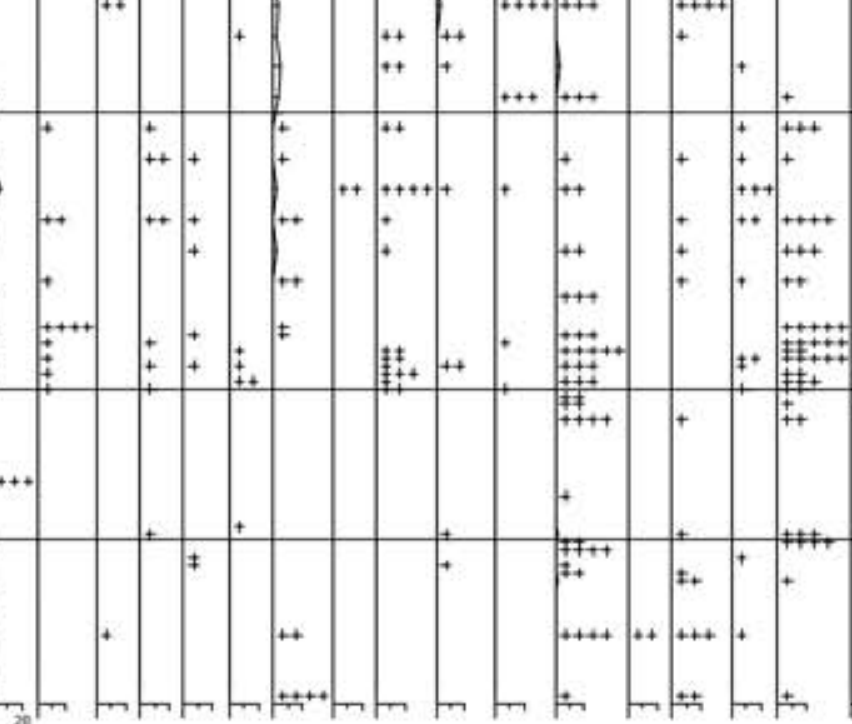

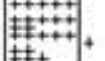
장

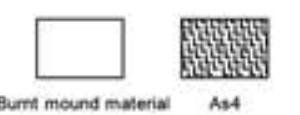





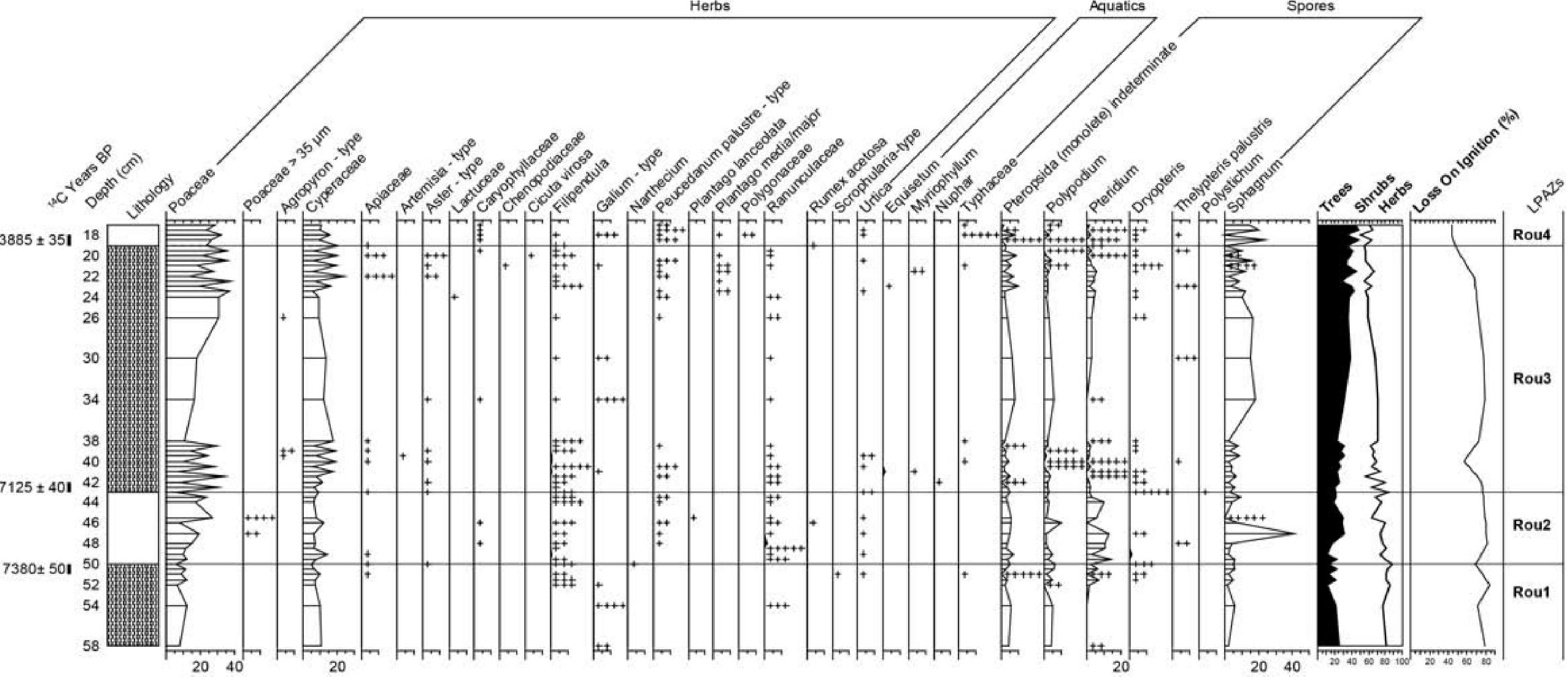




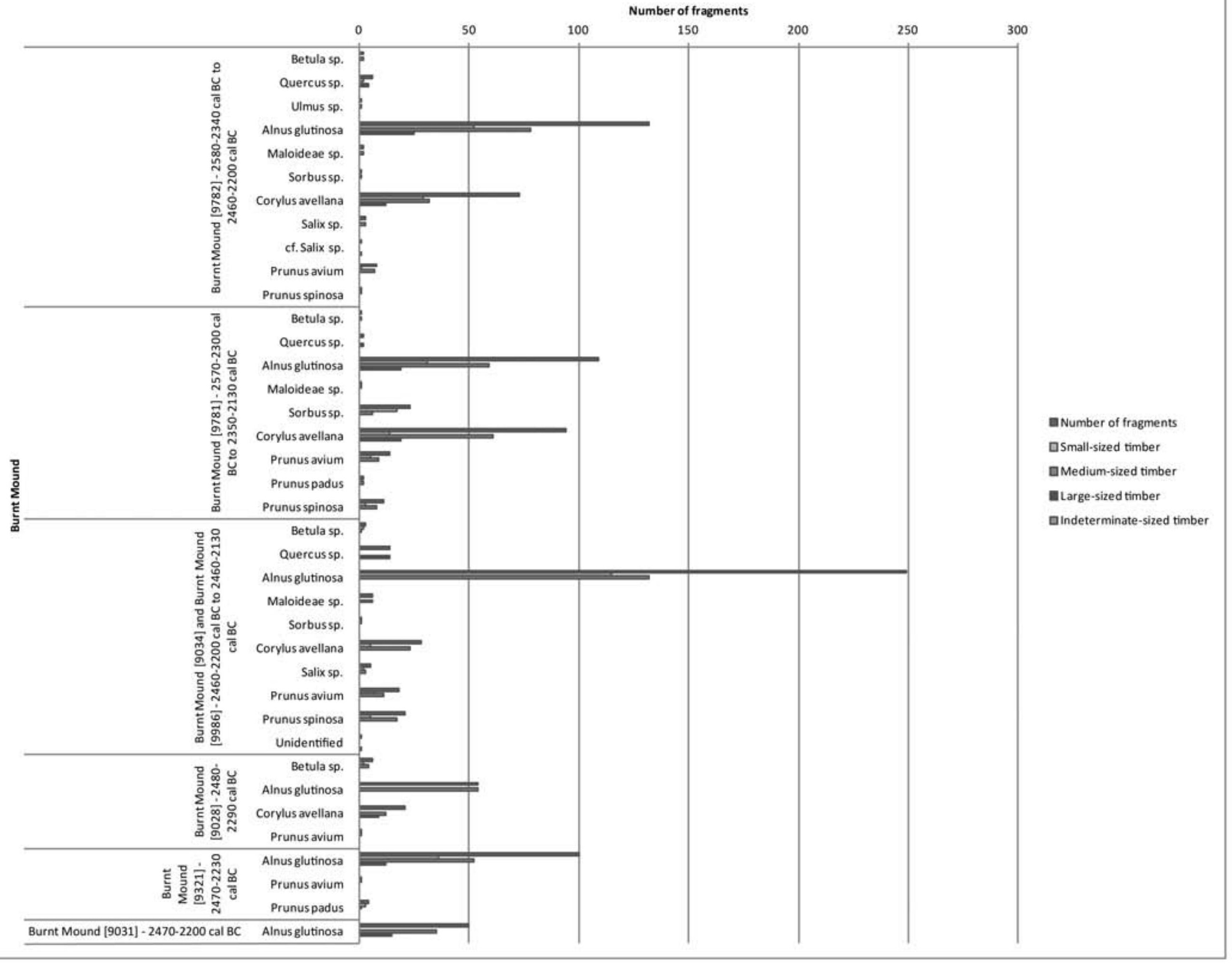




\begin{tabular}{|c|c|c|c|c|c|}
\hline Roughan & Depth (cm) & Material & $\begin{array}{c}\text { Lab } \\
\text { number }\end{array}$ & $\begin{array}{c}{ }^{14} \mathrm{C} \text { age } \\
\text { (BP) }\end{array}$ & $\begin{array}{l}\text { Calibrated } \\
\text { age range } \\
(95.4 \%)\end{array}$ \\
\hline \multirow[t]{3}{*}{ Monolith } & $18-19$ & $\begin{array}{l}\text { Corylus avellana } \\
\text { charcoal }\end{array}$ & $\begin{array}{l}\text { GU- } \\
15850\end{array}$ & $3885 \pm 35$ & $2466-2208 \mathrm{BC}$ \\
\hline & $42-43$ & $\begin{array}{l}\text { Peat - humic } \\
\text { acid }\end{array}$ & $\begin{array}{l}\text { GU- } \\
15852 \\
\end{array}$ & $7125 \pm 40$ & $6068-5913 \mathrm{BC}$ \\
\hline & $50-51$ & Bulk sediment & $\begin{array}{l}\text { Poz- } \\
46459 \\
\end{array}$ & $7380 \pm 50$ & $6385-6100 \mathrm{BC}$ \\
\hline Ballgawley & Depth (cm) & Material & $\begin{array}{c}\text { Lab } \\
\text { number }\end{array}$ & $\begin{array}{l}{ }^{14} \mathrm{C} \text { age } \\
\text { (BP) }\end{array}$ & $\begin{array}{l}\text { Calibrated } \\
\text { age range } \\
(95.4 \%)\end{array}$ \\
\hline \multirow[t]{2}{*}{ Monolith } & $91-92$ & $\begin{array}{l}\text { Peat - humic } \\
\text { acid }\end{array}$ & $\begin{array}{l}\text { GU- } \\
15849 \\
\end{array}$ & $3850 \pm 35$ & $2460-2200$ \\
\hline & 103-104 & $\begin{array}{l}\text { Corylus avellana } \\
\text { Charcoal }\end{array}$ & $\begin{array}{l}\text { GU- } \\
17350\end{array}$ & $3865 \pm 35$ & $2465-2210$ \\
\hline
\end{tabular}

